\title{
EL NOVECENTISMO COMO ENCRUCIJADA: ANTONIO DE HOYOS Y VINENT
}

\author{
Mercedes Comellas Aguirrezábal \\ Universidad de Sevilla
}

\begin{abstract}
Antonio de Hoyos y Vinent is one of the best known figures of the Spanish «decadentism». A successful author during the final years of Modernism, he gathered in his poetic the many ingredients that made up Spanish literature in the called Novecentismo. The study of his work makes it possible to revise the traditional period divisions of the beginning of the XX century while yielding a new approach to the concept of Novecentismo and presenting it as a crossroads of both new and old trends in the context of the deep transformation of the literary means of production and diffusion that took place at that time.
\end{abstract}

"El cerebro humano, cuanto más enfermo, cuanto más deformado y podrido está, más nobles, bellos y altos pensamientos destila"1. La declaración de Antonio de Hoyos y Vinent en su novela El banquete del Minotauro alcanza su verdadera dimensión en la tradición estética que moviera a Shelley a estremecerse ante la insólita belleza de la cabeza de Medusa $^{2}$. Una tradición que viviría en los comienzos del siglo XX un momento de intensa renovación y que excitó la vocación escritora de esta extravagante figura de la literatura novecentista española, animando en él una fantasía monstruosa que buscaba en las patologías de la rareza el signo de la distinción. Hoyos debió de sentirse, o gustó de creerse una de esas criaturas a las que su anormalidad y afanosa excentricidad convertía en seres exclusivos. Con esa convicción escoge un pasaje de su maestro Octave Mirbeau en El jardín de los suplicios (1898), como introito a una de sus más famosas novelas, El monstruo (1915):

“- ¡Monstruos...! ¡Monstruos! En primer lugar, no hay monstruos, y lo que tú llamas así, son formas superiores o extrañas a tu humana condición. ¿Acaso los dioses no son monstruos? ¿Es que el hombre de genio no es tan monstruoso como el tigre, la araña y todos aquellos individuos que viven por encima de las mentiras sociales, dentro de la resplandeciente y divina inmoralidad de las cosas...?"

Nuestro amante defensor de la teratología ostentó el mismo título nobiliario que su ilustre predecesor en las artes de la rareza sexual, el marqués de Sade: Antonio de Hoyos

\footnotetext{
${ }^{1}$ Antonio de Hoyos y Vinent, El banquete del Minotauro, Madrid, El Libro Popular, 1922, p. 29.

${ }^{2}$ La anécdota la cuenta Mario Praz en el primer capítulo de su clásico La carne, la muerte y el diablo en la literatura romántica, Caracas, Monte Avila Editores, 1969.
} 
fue marqués de Vinent, segundo vástago de una ilustre familia de la Grandeza de España, de padre embajador y hermano ministro de gobernación. Educado en el mismo colegio vienés que Alfonso XIII y estudiante después en Oxford, se entregó desde muy joven a veleidades literarias, para ingresar con ellas en los ambientes bohemios y convertirse en los años de la primera guerra mundial en famoso novelista erótico, mientras exhibía una homosexualidad que no le perdonaron muchos; sordo desde niño, mantenía sus conversaciones con ayuda de notas escritas y su misma voz desentonada recordaba aquella tara física. Nadie sospechó en aquellos años de éxito y dandismo que su corpulenta figura enjoyada acabara en las filas de la anarquía militante y muriese, víctima de la represión franquista, abandonado de todos, enfermo y medio ciego en una prisión madrileña.

La singularidad de su biografía adquiere rostro literario en la galería de monstruos que pueblan su obra narrativa, de cuya "degeneración teatralizada" participa en algo la monstruosidad del propio autor ${ }^{3}$. Quién sabe cuántos de ellos nacieron, como las visiones del último Goya, como consecuencia de esa sordera que, él mismo reconoce, "nos hace más concentrados, más observadores, y nos lleva a vivir una vida interior infinitamente más intensa..." "; su excentricidad misma pudo bien acentuarse por "el aislamiento en que la falta de oído nos sume [... y que] nos permite vivir una vida intensa, misteriosa, más nuestra"s.

Durante sus mejores años le rodeó una corte tan extraña como su figura, entre cuyos personajes recuerda González Ruano a la bailarina exótica Tórtola Valencia, el escultor Julio Antonio, la aristócrata lesbiana Gloria Laguna y el "extrañísimo marqués de Villalobar, que era otro monstruo de los buenos". Pero entre todos ellos, efímeras estampas del decadentismo novecentista, nos queda sobre todo el recuerdo de Hoyos como el protagonista por excelencia de esa secta singular. Lo concede sin titubear Gimferrer:

"si a un solo raro hispánico -al raro por excelencia- hubiera de nombrar, pocos dudarían: Antonio de Hoyos y Vinent"

\footnotetext{
${ }^{3}$ Eugenio de Nora, La novela española contemporánea, Madrid, Gredos, 1958, vol. I, p. 414. Para Cansinos (La nueva literatura IV, Madrid, Páez, 1925, p. 63), "el ciclo erótico de Hoyos y Vinent es un admirable florecimiento de monstruos".

${ }^{4}$ En entrevista de El Caballero Audaz, La Esfera n $^{\circ}$ 9, 5 de mayo de 1916, reproducida en J. M. Carretero, Lo que sé por mí, Madrid, Mundo Latino, 1922. Gregorio Marañón compara las visiones de Goya y Hoyos en su prólogo a Sangre sobre el barro: paisajes patológicos [1934] (reed. en Madrid, Cairel, 1993, p. 13): "Los paisajes españoles tenebrosos, alucinantes, febriles y ensangrentados de Antonio de Hoyos y Vinent, tienen, sin duda, su raíz en Goya".

${ }^{5}$ Prólogo para la novela La sombra de otro amor, de 1924. Blasco Ibáñez, en el prólogo a Los toreros de invierno, Madrid, Biblioteca Hispania, s.a, [1918], p. 21, busca en la sordera de Hoyos la causa de ciertas predilecciones temáticas: "Hoyos, a semejanza de todos los que viven sumidos en un silencio exterior, es aficionado a los relatos tremebundos, a los personajes perversos, a las escenas horrorosas." Y del mismo parecer, F. C. Sainz de Robles (en La promoción de "El Cuento Semanal», 1907-19255: (un interesante e imprescindible capitulo de la historia de la novela española, Madrid, Espasa-Calpe, 1975, p. 193) llega a afirmar que "por su enorme sensibilidad anormal y su total sordera se vio empujado -...- a una realidad deformada que alternaba con una imaginación capaz de crear monstruos".

${ }^{6}$ César González Ruano, Memorias. Mi medio siglo se confiesa a medias, Madrid, Tebas, 1979, p. 84.

${ }^{7}$ Pere Gimferrer, Los raros, Palma de Mallorca, Bitzoc, 1999, p. 92.
} 
Después de una etapa inicial de tendencia naturalista en la que nos detendremos más adelante ${ }^{8}$, Hoyos se convierte en uno de los autores más conocidos-que no reconocidos, podemos avanzar- del panorama literario. Apadrinado por el padre Coloma y la Pardo Bazán en sus comienzos, conseguiría en su momento de apogeo, entre los años 1910 y 1920, contar como prologuistas para sus novelas con figuras tan conocidas como las de Unamuno, Marañón, Simarro, Blasco Ibáñez, Linares Rivas, Benavente, Pardo Bazán, Cejador, Ortega Munilla, Martínez Sierra o Marquina.

Reconoce Gómez de la Serna que Hoyos "había preferido a todo ser literato"; su vocación le lleva a escribir sin descanso, mientras otros de su clase vivían la holganza privilegiada propia de sus circunstancias sociales. Además, por esa misma vocación, al marqués "le enloquecía la publicidad". Y logró conseguirla durante algunos años, según afirma Sáinz de Robles:

"Pocos novelistas han sido tan elogiados en vida, y con tanta hipérbole, como Hoyos y

Vinent. Pocos también tan desdeñados, después de muerto, por los mismos panegiristas"10.

Quizá el problema de los juicios sobre Hoyos, más allá de la mudable opinión con que la crítica debate sobre aquella novela erótica de modernistas rezagados y anacrónicos, esté en la interna contradicción de su propia obra, "que apenas conoce término medio entre lo pésimamente escrito y lo fascinante"11. Pero también, como ya se apuntaba antes, en la mixtura entre vida y literatura que el autor mismo y la crítica tras él han venido fomentando. Para M. Carmen Alfonso García, estamos ante un caso en el que la vida supera a la creación, pues en Hoyos lo fundamental es "la categorización de lo bello como discurso existencial que hace de la vida un complejo objeto de arte del que la escritura resulta sólo un pálido reflejo"; desde este punto de vista, el más interesante de todos los personajes de su galería es el propio autor ${ }^{12}$. Alfonso está repitiendo el planteamiento de Villena cuando afirmaba, en uno de los primeros trabajos que rescataron la figura del novelista, que

\footnotetext{
${ }^{8} \mathrm{M}^{\mathrm{a}}$ del Carmen Alfonso García marca las etapas de la obra narrativa del escritor sin distanciarse de lo que habían señalado antes Luis Antonio de Villena o Antonio Cruz Casado: 1) Primer periodo, que se abre con Cuestión de ambiente ( (1902-3?) y se prolonga hasta Los emigrantes (1909). Obras en su mayoría "de escándalo aristocrático". 2) Periodo de éxito. Novela decadente: desde Del huerto del pecado (1910) hasta 1925. 3) El tercer periodo prefiere el ensayo a la novela y se inicia con El origen del pensamiento (1924), (Alfonso García, Antonio de Hoyos y Vinent, una figura del decadentismo hispánico. Oviedo, Departamento de Filología Española, Universidad de Oviedo, 1998, p. 13). Más adelante matiza que tales fracturas no significan un cambio radical de motivos: "Al contrario, los elementos característicos de una determinada etapa seguirán teniendo vigencia en las posteriores, si bien con distinta importancia relativa" (p. 71, n. 1).

${ }^{9}$ Gómez de la Serna, Retratos completos, Madrid, Aguilar, 1961, p. 470.

${ }^{10}$ Sáinz de Robles, La promoción de «El cuento semanal», op. cit., p. 194.

${ }^{11}$ Gimferrer, Los raros, op. cit., p. 94.

12 Alonso García, "De la decadencia al anarquismo: Hoyos y Vinent en El Sindicalista (1935-39)", Archivum XXXIX-XL, (1989-1990), pp. 7-50, p. 7.
} 
"La gran atracción de la literatura de Hoyos y Vinent es que supone la prolongación, la imagen, la materia misma de su vida [...] Antonio de Hoyos y Vinent fue una gran máscara; [...] en él es más importante el personaje que la obra"13.

Quedaría así incluido nuestro marqués en la nómina de aquellas máscaras literarias que, desde Baudelaire y sobre todo con Verlaine, sirvieron a tantos autores (vaya entre las mejores de los nuestros la de Valle-Inclán) para diseñar y habilitar la propia vivencia. Maquillar la vida de literatura y crear paralelos entre personaje y autor en una voluntaria confusión especular es desde luego una práctica habitual de los alter ego que Hoyos y Vinent prodigó en sus páginas: el pintor Juan Norberto de El mito de Orfeo (1925), aristócrata y sordo, está muy influido en su comportamiento por prejuicios literarios; y Julito Calabrés, su doppelgänger más frecuente, "un curioso enfermo de literatura" -como se le describe en El secreto de la ruleta (1916)-, "a fuerza de querer vivir la enigmática vida de sus héroes, llegó a asimilarse algunas de sus sensaciones y se creía de buena fe un símbolo de la décadence latine" ${ }^{14}$.

No es objetivo de este estudio descubrir al hombre que se oculta tras la máscara literaria, sino observar la máscara misma, sus componentes y tejidos, y cómo se construye históricamente, como cualquier producto artístico. El análisis obligará a plantear, como suele ocurrir en el caso de los autores secundarios, la validez de una terminología periodológica, habitual en los manuales de historia literaria y que se demuestra inoperante y lábil al aplicarla.

En el recorrido que se propone usaremos como fuentes no sólo las obras de ficción de Hoyos, sino también sus críticas y reseñas literarias, hasta ahora ignoradas en los estudios a él dedicados ${ }^{15}$ y que sin embargo pueden colaborar enormemente a la disección de su poética.

\section{LA LITERATURA DEL NOVECENTISMO Y LA OBRA DE HOYOS Y VINENT.}

En la historiografía literaria se aplica tradicionalmente el controvertido membrete de Novecentismo al periodo que media entre los escritores finiseculares -hasta hace poco tiempo agrupados por la crítica en la llamada generación del 98- y la confirmación de los movimientos de vanguardia a mediados de los años 20. Suele justificarse la cohesión novecentista entendiendo a sus protagonistas como una suerte de continuadores del 98, pero en una línea que intenta superar por medios intelectuales el individualismo romántico y la impresión de agotamiento propia de aquellos autores ${ }^{16}$. Así concebido, el Novecentismo

\footnotetext{
${ }^{13}$ Luis Antonio de Villena, “Antonio de Hoyos y Vinent y su novela decadente”, Ínsula 348 (nov. de 1975), pp. 1 y 12.

${ }^{14}$ Hoyos y Vinent, Frivolidad, Madrid, 1905, pp. 119 y 140-1; cit. por Luis S. Granjel, "Vida y literatura de Hoyos y Vinent", Cuadernos Hispanoamericanos n 285 (marzo de 1974), 489-503, pp. 494-5.

${ }^{15}$ Sobre el periodismo de Hoyos ha trabajado $\mathrm{M}^{\mathrm{a}}$ del Carmen Alfonso García: "De la decadencia al anarquismo: Hoyos y Vinent en El Sindicalista (1935-39)", Archivum XXXIX-XL, (1989-1990), pp. 7-50 y "Las colaboraciones de Hoyos y Vinent en «La Esfera» (1914-1931): un inventario bibliográfico", Angélica (1992) n 3, pp. 123-141.

${ }^{16}$ Evitando la etiqueta de Novecentismo, Mainer describe como sigue a esa nueva generación: "un grupo bastante
} 
tendría como mentor y principal representante a Ortega, figura nuclear de un grupo elitista de intelectuales en cuya nómina suele incluirse a Pérez de Ayala, Gabriel Miró, Eugenio d'Ors, Azaña, Gómez de la Serna, Luis Araquistáin, Díez-Canedo y en ocasiones a Juan Ramón Jiménez. El grupo se articuló, según Manuel Bueno en Poniente solar (1931), como generación "fría y culta, educada en lo universal y mejor armada para la crítica que para la creación, no podía ocultar su desprecio por aquella literatura convencional que lo deformaba todo"17.

\section{ALGO SOBRE EL MERCADO LITERARIO: LOS INTELECTUALES Y LA NOVELA POPULAR.}

Pero frente a la visión de Bueno, aplicada después por la historiografía literaria clásica, el punto de vista de otros contemporáneos nos recuerda una realidad mucho más compleja y de la que dejan constancia los trabajos de José Carlos Mainer ${ }^{18}$ o el estudio de Luis Fernández Cifuentes, Teoría y mercado de la novela en España, del 98 a la República. En sus páginas comprobamos que los grandes nombres habituales hoy en los manuales fueron en aquellos años mucho menos difundidos que los de una heterogénea y pululante corte de escritores de segunda fila, de los que sólo guardan boy recuerdo los eruditos. Incluso, más allá de esa variación de perspectiva, Fernández Cifuentes da pruebas de una conflictiva relación entre dos partidos, el de los novelistas intelectuales y el de los populares, de la que es suficientemente expresiva la declaración de Baroja en Las horas solitarias (1920): "Blasco Ibáñez es un novelista público y yo soy un novelista privado"19.

más compacto de intelectuales, menos radicales que reformistas, preocupados por lo que Ortega llamaba la «competencia» técnica y decididos a fusionar un liberalismo progresista con un nacionalismo más estético que otra cosa." No deja de ser simbólica, en ese relevo generacional, la muerte, "en un breve espacio de tiempo, de tres figuras trascendentales del fin de siglo: Joan Maragall, [...] encarnación viva del modernisme romántico e iberista; Joaquín Costa, patriarca del regeneracionismo populista [...]; Marcelino Menéndez Pelayo, infatigable adalid de la erudición positivista"; de la significación del cambio dan cuenta sus respectivos sucesores: "la eficacia discreta y brillante del noucentisme, amparado en las instituciones de la flamante Mancomunitat", "la organización intelectual de la "Liga para la Educación Política Española»" y "la sólida actuación colectiva del Centro de Estudios Históricos dirigido desde 1910 por Ramón Menéndez Pidal". Mainer, "La llamada generación del 98: otros puntos de vista", Actas del Congreso "Los 98 ibéricos y el mar» II. La cultura en la península ibérica, Madrid, Sociedad Estatal Lisboa 98-Fundación Tabacalera, 1998, pp. 31-2. Libro clásico sobre concepto de Novecentismo -y necesitado de revisión- es el de G. Díaz-Plaja: Estructura y sentido del Novecentismo español, Madrid, Alianza, 1975.

${ }^{17}$ Cito por Felipe B. Pedraza y Milagros Rodríguez, "La promoción novecentista o de 1914", Manual de literatura española X. Novecentismo y vanguardia, Pamplona, Cenlit, 1991, p. 34.

${ }^{18}$ Además de varios capítulos de su La Edad de Plata (1902-1939). Ensayo de interpretación de un proceso cultural, (Madrid, Cátedra, 1983), deben consultarse también del mismo: "Literatura burguesa, literatura pequeñoburguesa en la España del siglo XX”, en Jean-Francois Botrel, Serge Salaun y F. Yndurain, Creación y público en la literatura española. Madrid, Castalia, 1974, pp. 162-180; y "1900-1910: New Literature, New Publics", en Wlad Godzich y Nicholas Spadaccini (eds.), The Crisis of Institutionalized Literature in Spain. Minneapolis, Prisma Institute, 1988, pp. 195-227.

${ }^{19}$ Luis Fernández Cifuentes, Teoría y mercado de la novela en España, del 98 a la República. Madrid, Gredos, 1982, pp. 128s. De la acritud a la que en ocasiones se llegó en la polémica puede ser ejemplo la que mantuvieron El Caballero Audaz y Araquistáin en 1922 y que "revela el tipo de relaciones que los intelectuales mantenían con los escritores populares" (ibid, p. 132-3, n. 24). 
Cuando al considerar la producción literaria del periodo se habla de "crisis de la novela", hay que referirse sólo a los primeros ${ }^{20}$. Las novelas del segundo grupo, destinadas al consumo inmediato, llenaron con sus títulos las colecciones populares y se convirtieron en nutriente habitual de un público lector ávido y devoto. Reconoce César González Ruano en sus memorias que en su formación literaria -durante los años 20-, no tuvieron gran papel los clásicos, "ni Cervantes, ni Quevedo, ni Gracián, ni Góngora, sino Zamacois, Insúa, Hoyos y Vinent y Felipe Trigo" ${ }^{21}$. Y José Alfonso en sus remembranzas Del Madrid del cuplé confiesa que

"En aquel Madrid del cuplé -para vergüenza nacional- Azorín, Baroja, Valle-Inclán, Unamuno, Pérez de Ayala, Ortega, Miró... apenas contaban con lectores. Por contra, López de Haro, Insúa, Pedro Mata, El Caballero Audaz, Zamacois, Álvaro Retana, Joaquín Belda... cortaban el bacalao literario"'s2.

El propio Hoyos, en la más citada de sus entrevistas, la que le hizo José María Carretero, El Caballero Audaz -militante por otra parte del mismo bando-, para La Esfera, responde a la consulta de sus gustos literarios admitiendo:

"Me encanta el estilo de Valle-Inclán, la pausada serenidad de Azorín y la energía de Baroja; pero sobre todo me gustan extraordinariamente las novelas de Zamacois... El otro es el libro que más huella ha dejado en mi espíritu."'23

Unamuno había pedido años antes en su artículo "Los escritores y el pueblo" (1908) que el artista se alejase de lo vulgar, ya que "ni la fuerza ni la pasión están en el vulgo, ni hay nada más deleznable y pasajero que los escritores llamados populares"24. La misma repugnancia encontramos en Ortega y en Pérez de Ayala, padrinos de una vuelta a cierto clasicismo, o al menos a un antirromanticismo, desde el que trataron de desechar cierta temática literaria y su aderezo de formas decadentes y modernistas. En ellas (Ortega se refiere en sus críticas a D'Annunzio sobre todo) el gusto por las palabras, convertidas en valores por sí mismos, se entroniza, dejando apenas espacio para lo humano. Según Unamuno era aquella una literatura de oficio, alquímica, indiscernible de la literatura vulgar; de forma similar a Ortega, vinculaba vulgaridad con decadentismo.

Pero aquellas quejas de los intelectuales no encontraron eco en el mercado de la novela, y no es de extrañar entonces que González Ruano, uno de los críticos más importantes del periodo, después de señalar sus preferencias lectoras entre los escritores más considerados, admita estimar - a veces por razones no literarias- a "alguno de los del novecientos, que fue una generación muy trabajadora y de vida literaria, pero de obra francamente floja", en la

\footnotetext{
${ }^{20}$ A no ser que consideremos, como José M. Fernández Gutiérrez (La novela corta galante: Felipe Trigo, Barcelona, PPU, 1989), aquellas colecciones como explícito síntoma del agotamiento de la novela.

${ }^{21}$ González-Ruano, Mi medio siglo se confiesa a medias, op. cit., p. 62.

22 José Alfonso, Del Madrid del cuplé, Madrid, Cunillera, 1972, p. 41.

${ }^{23}$ J. M. Carretero, "Nuestras visitas. Antonio de Hoyos y Vinent", La Esfera no 110 (1916).

${ }^{24}$ Apud. Fernández Cifuentes, Teoría y mercado de la novela, op. cit., p. 62.
} 
que incluye a Carrere, Noel, López de Haro, José Francés, Hoyos y Répide ${ }^{25}$, dejando al margen del título "del novecientos" los nombres de aquellos autores antes mencionados y a quienes el canon académico concede la máxima representatividad de su generación.

Las declaraciones de Unamuno obligan a buscar el origen del problema en el modernismo, "mercancía literaria desvalorizada en el mercado filisteo finisecular", ya que el gusto literario de la burguesía española seguía vinculado a la estética realista y naturalista ${ }^{26}$. Y de añadidura también a plantearnos la verdadera naturaleza del panorama literario en la España de comienzos del siglo XX cuya transformación, más que a motivaciones generacionales dependientes de perspectivas ideológicas, tiene que ver -como explica José Carlos Mainer- con los "cambios de naturaleza estructural en el mercado literario: la ampliación del público a costa de las nuevas clases medias urbanas (y de una pequeña capa del proletariado consciente), la revolución de la difusión de la letra impresa (fundamentalmente, en la nueva prensa periódica y en las revistas ilustradas) y la consiguiente mayor afluencia de escritores -...- que estrenan la función orientadora del «intelectual» o se definen a través de la subversiva apostura del «bohemio»"27.

Interesa sobre todo hacer hincapié en esta perspectiva porque Hoyos se mostró activo protagonista de estas verdaderas articulaciones del cambio: desde su industriosa y esforzada participación en los recién inaugurados mecanismos que el mercado buscó para la narrativa, en su papel como plumífero habitual de la prensa periódica -fundador incluso de una revista ${ }^{28}$, y hasta en sus coqueteos con las posiciones intelectuales o bohemias, muestra ser un transeúnte diligente de las encrucijadas de la nueva literatura.

Para encontrar una manera de entrar en aquel mercado las nuevas tendencias modernistas hubieron de plantearse una fórmula promiscua: entregarse a las leyes de oferta y demanda aprovechando lo que le restaba de su antigua familiaridad con ciertas claves del naturalismo; surgirá así una novela de segunda clase en las colecciones de novela corta, una novela pseudonaturalista, decadente y -también ha sido a veces denominada así por la crítica- pseudomodernista. Y, haciendo frente a la opinión de los grupos de la intelectualidad más exigente, fue esta la fórmula que triunfara en los gustos lectores durante al menos dos décadas.

Felipe Trigo fue uno de los primeros en disfrutar simultáneamente del éxito y la repulsa de la élite. El título de su conferencia en el Ateneo de Madrid en 1907, con la que pretende defenderse de la persecución de los más intransigentes, deja constancia de las condiciones del enfrentamiento: "La impotencia de la crítica ante la importancia de lo emocional en la

\footnotetext{
${ }^{25}$ González Ruano, Memorias, op. cit., p. 121.

${ }^{26}$ Manuel Aznar Soler, "Decadentismo y bohemia literaria”, Ínsula, (1998) n 613, pp. 28-30; p. 30.

${ }^{27}$ José Carlos Mainer, “La llamada generación del 98: otros puntos de vista”, op. cit., p. 30.

${ }^{28}$ Gran Mundo y Sport (1906-1907), de exquisita edición a lo art decó y alto precio, curiosa mezcla de ensayos histórico-monárquicos, crónicas de sociedad, noticias deportivas, apuntes literarios y poemas.
} 
novela moderna"29. Con Trigo la novela popular encuentra en la temática del erotismo el filón que mejor supo aprovechar y que mayores éxitos le proporcionaría.

La respuesta -impotente, como demostraba Trigo- desde el grupo contrario no se hizo esperar: ya en 1908 Ortega pronostica:

"El nivel intelectual va bajando tanto y tan deprisa en estos confines de la decadencia, que dentro de poco no habrá academias ni teatros, sino que sentados los españoles en torno a enormes mesas de café, nos contaremos cuentos verdes".

Simultáneamente Maeztu proponía crear una Liga Antipornográfica que contara incluso con el apoyo de políticos como Pablo Iglesias (por otra parte corresponsal de Trigo, al que le unió larga $\left.\operatorname{amistad}{ }^{30}\right)$; y dos años después Azorín muestra su alarma desde las páginas de $\mathrm{ABC}$ porque "la nueva generación de escritores españoles está completa y desenfrenadamente entregada al más bajo y violento erotismo". En 1911 Luis Terán hizo una encuesta desde Nuestro Tiempo sobre "El erotismo en la novela" y las respuestas se divulgaron en la "Revista de revistas" de La España Moderna en agosto de 1911". Para entonces la literatura erótica había encontrado cauce de difusión en las colecciones de novela corta, un fenómeno editorial que nos conecta con Hoyos y Vinent y con el papel de la prensa periódica, ya que estas colecciones corresponden al formato de "revistas semanales literarias".

Si las novelas sueltas exigían al lector un desembolso de tres pesetas por ejemplar, estas colecciones permitían comprar por 30 céntimos relatos de ficción sin grandes pretensiones, destinados a un público mayoritario. La cultura de masas exigía del mercado editorial una renovación de sus planteamientos que tuviera en cuenta la importancia de los nuevos destinatarios de la cultura y buscara mercado nuevo en la clase media baja. El sistema así constituido requiere un escritor profesionalizado, que tenía ya su modelo en el autor de folletines a lo Fernández y González, dispuesto a no hacer ascos a unas pautas productivas que imponían la urgencia y resultaban afectas al uso de clichés pueriles y a toda clase de estereotipos.

La primera colección fue idea y fundación de Eduardo Zamacois, que la tituló $E l$ Cuento Semanal (1907-1912). Le seguirían las de Los Contemporáneos, El Libro Popular, La Novela del Bolsillo, La Novela Corta (que logró un enorme éxito con tiradas que superaban a veces los 100.000 o 300.000 ejemplares), La Novela Semanal, más conectada con tema erótico y que puso la moda de contrato de "colaboradores únicos", bien pagados, entre los que contó con Hoyos, Insúa, López de Haro, Carmen de Burgos (Colombine) o

\footnotetext{
${ }^{29}$ Según Fernández Cifuentes (Teoría y mercado de la novela, op. cit., p. 77), "hasta la muerte de Galdós (1920) no se produjo un fenómeno literario o seudoliterario que polarizara de tal modo a los críticos" como el caso de Felipe Trigo y la novela erótica.

${ }^{30}$ Fernando García Lara, El lugar de la novela erótica española. Granada, Diputación Provincial, 1986, p. 98.

${ }^{31}$ Fernández Cifuentes, Teoría y mercado de la novela, op. cit., pp. $91 \mathrm{~s}$.
} 
Carrere; también deben mencionarse La Novela de Hoy, La Novela de Noche (esta última también de contenido erótico) y La Novela Mundial ${ }^{32}$.

Hoyos, asiduo colaborador desde el principio y una de las "estrellas" de este medio literario ${ }^{33}$, defendió en varias ocasiones la que él considera trascendental función de las colecciones: al tratar "El problema del libro" y tras recordar que en España cada vez lee más gente, asume la enorme responsabilidad del escritor de educar al pueblo:

"¡Hay tantas inteligencias jóvenes, ansiosas de guía y de luz que los esclarezca, y tantos corazones sanos y nobles hambrientos de pan espiritual!" “Quién duda que los que para el público escribimos contraemos una responsabilidad moral, que tenemos una misión patriótica, educadora, moralizadora que cumplir?'334

(Casi pueden leerse como una ironía grotesca sus palabras si recordamos que lo que por aquellos años Hoyos está presentando en sus novelas a esa sana juventud con hambre espiritual es una galería de monstruosidad patológico-sexual de la que dan cuenta los mismos títulos: El caso clínico, Las Hetairas Sabias, El Oscuro Dominio, La atroz aventura o La Procesión del Santo Entierro.)

La conciencia de su misión como intelectual -sincera o pura pose- le invita a elogiar el proyecto de Zamacois de crear una colección de novelas que "cultivan el espíritu de modestos medios pecuniarios y despiertan su pasión por leer", insistiendo de esta forma en la intención didáctica de la que hacían gala sus editores ${ }^{35}$.

\footnotetext{
${ }^{32}$ La bibliografía sobre las colecciones es muy amplia: por citar los títulos más conocidos recordemos los estudios de Federico Carlos Sainz de Robles (La novela corta española: promoción de "El Cuento Semanal" (1901-1920), Madrid, Aguilar, 1952 y La promoción de "El Cuento Semanal", op. cit.), los trabajos de Luis S. Granjel ("La novela corta en España (1907-1936)", Cuadernos Hispanoamericanos LXXIV (1968) pp. 477-508 y sobre todo su Eduardo Zamacois y la novela corta, Universidad de Salamanca, 1981), el de Manuel Martínez Arnaldos, "El género novela corta en las revistas literarias (Notas para una sociología de la novela corta, 1907-1936)", Estudios literarios dedicados al profesor Mariano Baquero Goyanes, Universidad de Murcia, 1974, pp. 233-250; o los análisis particulares dedicados a las distintas colecciones, como el de J. C. Mainer, "El Cuento Semanal (19071912): Texto y contexto"; en Yves-Rene Fonquerne (ed.). Formas breves del relato. Madrid, Secretariado de Publicaciones de la Universidad de Zaragoza-Casa de Velázquez, 1986, pp. 207-220; o el Marisa Siguán sobre La Novela Ideal (Literatura popular libertaria (1925-1938), Barcelona, Península, 1981.

${ }^{33}$ Entre las colecciones en las que colabora podemos recordar El Cuento Semanal, Los Contemporáneos, La Novela Semanal, La Novela de Hoy, La Novela de Noche, Los Novelistas y Los 13.

${ }^{34}$ Hoyos y Vinent, "El problema del libro II", El Día, n 13.303, 8 de abril de 1917, p. 6. Y "Comentario. El verso de Ayala", El Día n 13.415, 30 de julio de 1917, p. 2.

${ }^{35}$ Mainer, La Edad de Plata, op. cit. p. 74: La colección La Novela Corta tiene "intención didáctica -lo que llaman sus editores en forma bastante campanuda «nuestro apostolado de divulgación literaria»". En esta orientación tiene importancia nada desdeñable la afición del público femenino -muy necesitado de esa "orientación didáctica", según criterio compartido en la época- a la lectura de novelas; de hecho, hubo varios proyectos de colecciones dirigidas a ese sector, siempre numeroso. Desde otro punto de vista, pero compartiendo un mismo desprecio por las mujeres, se queja Unamuno en el Prólogo a Tres novelas ejemplares (ed. en A. y G. Gullón, Teoría de la novela, Madrid, Taurus, 1974, 97-105), culpando a las lectoras de la decadencia de la novela: "Sé que en España hoy el consumo de novelas lo hace principalmente mujeres. ¡Es decir, mujeres, no!, sino señoras y señoritas. Y sé que estas señoras y señoritas se aficionan principalmente a leer aquellas novelas que les dan sus confesores o aquellas otras que se les prohiben, o sensiblerías que destilan mangla o pornografías que chorrean
} 
La misma intención es la que demuestran las colecciones de novelas libertarias, como la fundada por los Montseny con el nombre de La Novela Ideal y que parte de la convicción de que la ignorancia es un lastre para los sometidos y la instrucción la mejor arma revolucionaria. Desde ese presupuesto y aprovechando el cauce ya explorado por la novela corta periódica, que se había demostrado para entonces de gran difusión, crearon una colección cuyos principios eran propagar la sociedad libertaria, dirigirse a los sentimientos y ser en la mayor medida comprensibles para todo tipo de lectores ${ }^{36}$. No hacían con ello sino llevar al terreno del apostolado político una orientación socializante de la que participaron otros editores en principio menos comprometidos, desde Zamacois a Artemio Precioso, fundador de La Novela de Hoy y La Novela de Noche y que combinaba su actividad como autor de novelas galantes y la dirección de varios semanarios humorísticos o eróticos con proyectos como el periódico Los Hombres Libres, de tendencia izquierdista radical, abortado por la censura durante la dictadura de Primo de Rivera.

Esta tendencia política de los editores casaba bien con la línea estética del grueso de las novelas. La mayoría de los autores que en colaboraron en aquellas colecciones resultan representantes o herederos de las fórmulas narrativas de fines del XIX, o se adhieren al nuevo realismo populista: Galdós, Pardo Bazán, Palacio Valdés, Valera, Jacinto Octavio Picón, Blasco Ibáñez, Sawa, Noel, aunque encontramos algunos nombres del llamado 98 (Baroja, Unamuno, Benavente, incluso Valle-Inclán) y con aún menor frecuencia otros de las nuevas generaciones (Gómez de la Serna, Cansinos Asséns, Pérez de Ayala, Martínez Sierra). Entre todos ocupan un lugar fundamental los denominados novelistas eróticos: Felipe Trigo, Pedro Mata, Alberto Insúa, Hoyos y Vinent, Rafael López de Haro, Álvaro Retana, Joaquín Belda..., en general continuadores de la línea abierta por Trigo y que irá evolucionando en diversas direcciones desde aquel singular naturalismo entregado a la temática sexual. En conjunto, y como puede observarse ya en la primera colección, El Cuento Semanal, se reúnen en esta modalidad varias tendencias coetáneas: costumbrismo, naturalismo, realismo, historicismo y erotismo, con preponderancia numérica considerable de las distintas fórmulas realistas y naturalistas, y una orientación temática que privilegiaba las tramas con fuerte componente erótico.

Para Federico Sainz de Robles como para Luis S. Granjel, Hoyos encuentra su lugar en la historiografía literaria junto a los autores agrupados en la llamada "Promoción de El Cuento semanal", título de aquella primera colección de novela breve iniciada en 1907 y

pus. [...] ¡Y así anda nuestra literatura novelesca!" (ed. cit., p. 104). En otro tono García Sanchiz se burla en La Esfera: "De algún tiempo a esta parte, escritores y cupleteras rivalizan en anunciarse con la misma advertencia en programas y gacetillas editoriales. La de que tienen la predilección del público femenino", ("Novelistas para mujeres", 27 de agosto de 1921). Y en la relación de «novelistas para mujeres» que hizo el mismo autor: "Lo mismo Ricardo León, para uso de familias, que Hoyos y Vinent, destructor de familias; el mefistofélico Benavente y Pedro Mata [...], y los demás de la serie, poseen su feudo en los jardines del eterno femenino" (Fernández Cifuentes, Teoría y mercado de la novela, op. cit., p. 124 n. y 129). Sobre esta cuestión puede consultarse también: José María Martínez Domingo, "La prosa de Manuel Gutiérrez Nájera: El público femenino del Modernismo", en F. Sevilla y C. Alvar (eds.). Actas del XIII Congreso de la Asociación Internacional de Hispanistas, III. Madrid, Castalia, 2000, pp. 233-241.

${ }^{36}$ José Luis Gutiérrez Molina, "La formación de un anarquista", El Anarquismo en Chiclana. Diego Rodríguez Barbosa, obrero y escritor (1885-1936), Excmo. Ayuntamiento de Chiclana, 2001, p. 109. 
que integra a los que Sainz de Robles considera epígonos del 98 y eslabón con los novelistas de posguerra (de hecho, para Sainz de Robles, Hoyos es antecedente del llamado tremendismo) ${ }^{37}$. Pertenece, por el padrinazgo que le protegió en sus primeros pasos (de Coloma y la Pardo Bazán), por la mutua admiración que le unió a Blasco Ibáñez y por su estrecha relación con el mercado de las colecciones, al grupo de los autores populares, con los que también habrá de compartir, como se verá más adelante, conceptos y valores de teoría poética.

\section{NATURALISMO}

La trayectoria novelística de Hoyos se inicia con una primera etapa naturalista que la crítica -tanto la coetánea al autor como la de la actualidad académica- coincide en prolongar hasta 1907 o 1909, lo que significa aceptar de añadidura que su formación y aprendizaje se forjaron sobre esta impronta ya consolidada en aquellos años ${ }^{38}$. No es por tanto de extrañar que ciertos postulados y maneras del naturalismo se mantengan a lo largo de todo su itinerario, incluso cobren nuevos bríos en su periodo final, del que hablaremos más adelante. La continuidad de esta permanencia encuentra doble justificación si tenemos en cuenta que muchas novelas de Hoyos utilizan como parte habitual de sus decorados esos "bajos fondos" que habían sido tan frecuentes en la narración naturalista. De ahí que Luis Antonio de Villena pueda encontrar en sus relatos "la prosa del más enjoyado modernismo" ensartada en "cuadros naturalistas" 39 .

No es el naturalismo de Hoyos y Vinent una marca de excepción entre sus contemporáneos: Mainer se refiere, para aquella generación de autores que Sainz de Robles denomina "promoción de El Cuento Semanal", a "novela postnaturalista (o quizá mejor, el segundo naturalismo)", que se diferencia del primero porque con su "aparente dispersión de tendencias" "subraya la disgregación de la realidad" ". Si en el naturalismo de finales del siglo XIX aún el mundo puede presentarse en la narrativa como un todo orgánico, en esta segunda fase el fragmentarismo de la realidad impide cualquier posición holística.

Como cultivador de una narrativa de raigambre naturalista, Hoyos vuelve a situarse en la estela de la tradición realista decimonónica que, según vimos, fortalecía al grupo de los autores 'populares' frente al "antirrealismo" de los intelectuales. Resulta consecuente con

\footnotetext{
${ }^{37}$ Federico Sainz de Robles, La Promoción de El Cuento semanal, op. cit.; Luis S. Granjel, "La novela corta en España", op. cit., p. 2 y 55.

38 José M. Carretero, «El Caballero Audaz», en el prólogo que escribe a la novela de Hoyos La Procesión del Santo Entierro (Madrid, Hispania [s.a.] [1917]), identifica a su autor con Coloma y comparte con Cansinos (Poetas y prosistas del Novecientos) la idea de que el primer modo novelesco de Hoyos puede definirse como "crónica del mundo de la aristocracia, al modo de la herencia naturalista adobada de high life". Por su parte Alfonso García ( Antonio de Hoyos y Vinent, op. cit., p. 84) recuerda que la primera novela del marqués, Cuestión de ambiente, da razón ya en el propio título del ingrediente naturalista, pues ese ambiente es el medio del que surgen los conflictos. Advierte sin embargo que no encontraremos en sus páginas indicios de un determinismo radical, ni elaboración del concepto de herencia.

${ }^{39}$ L. A. de Villena, “Antonio de Hoyos y Vinent y su novela decadente”, op. cit., pp. 1 y 12.

${ }^{40}$ J. C. Mainer, "La evolución del naturalismo en la novela y el teatro", Historia y crítica de la literatura española VI: Modernismo y 98, F. Rico (dir.), Barcelona, Crítica, 1979, p. 189.
} 
esta posición que al reseñar Mare Nostrum tome claro partido en la contienda al conceder a Blasco -contra el que se cebaba particularmente la campaña antipopulista- el cetro de la novela española contemporánea, precisamente por su capacidad realista ${ }^{41}$. Blasco responderá al elogio escribiendo en la Revue Mondiale sobre el talento de Hoyos para pintar a personajes que parecen enteramente vivos, devolviéndole a un tiempo la cortesía y haciéndolo aliado en una misma concepción de lo narrativo.

Desde cualquier perspectiva el naturalismo resulta fundamental para entender la obra de Hoyos. Una lectura somera de sus relatos demuestra que sobre los más significativos personajes de aquella particular galería suya pesa el tributo inevitable de herencia y medio: la educación recibida, a la que tanta importancia y espacio narrativo se concede, y las circunstancias del ámbito social, explicarán o incluso determinarán el carácter de las figuras: desde la debilidad de Álvaro Navarrete en Mors in vita o la frivolidad de María de la Paloma en El crimen del fauno, resultados culpables de herencia genética y mala educación, a los ejemplos más explícitos de María de las Angustias en El caso clínico y Sol Moncada en El árbol genealógico ${ }^{42}$. Lo había visto ya Eduardo Gómez de Baquero en su reseña a La decadencia. Los emigrantes, publicada en El Imparcial en 1909:

"El Sr. Hoyos vuelve a reproducir [...] una tesis que le es grata [...]: la influencia que el ambiente corruptor de una sociedad frívola y viciosa, puede ejercer sobre caracteres maleables y almas débiles. En todas sus novelas hay algo de esto, que en la última, Los emigrantes, resalta con mucha más viveza."

Por otra parte no cabe olvidar que la otra clasificación periodológica que suele servir para encuadrar a Hoyos y Vinent -la de novelista erótico- nos conduce de nuevo a la conexión naturalista: como sostiene García Lara, "desde un punto de vista literario la cuestión parece clara: naturalismo y positivismo son las bases de esta narrativa [erótica]"43.

El mismo Hippolyte Taine había establecido la filiación sexual del realismo en $D e$ l'ideal dans l'art; más directamente, los intereses «científicos» del Naturalismo justificaban su curiosidad erótica. Por otra parte, la literatura erótica proponía la «cuestión sexual» como centro y eje sobre el que gira la contradicción social, lo que implica "pensar que el sexo está en el origen de la existencia, que constituye el principio de la vida y de sus sentidos"44. Médicos y novelistas compartían un extraordinario interés en el asunto, y los

\footnotetext{
${ }^{41}$ Hoyos y Vinent, "Los libros de la semana", El Día, 2 de abril de 1918. Y en otro artículo anterior ("El arte en el cinematógrafo. Blasco Ibáñez y Sangre y arena. Una película española", El Día, n 13.334, 9 de mayo de 1917, p. 6) había afirmado: "Blasco Ibáñez es un hombre admirable [...] que debiera ser modelo de muchos españoles", posee "una visión prodigiosa de la vida" y "sabe luego reflejar en sus páginas la realidad misma".

${ }^{42}$ A. Cruz Casado anota de pasada la importancia del factor herencia para El caso clínico y El árbol genealógico en "La novela erótica de Antonio de Hoyos y Vinent", Cuadernos Hispanoamericanos 426 (1985), 101-116.

${ }^{43}$ Fernando García Lara, El lugar de la novela erótica española, op. cit., p. 29. Isabel Román Gutiérrez observa esa conexión para el caso de Alberto Insúa: "Resulta inevitable mencionar la evidente -aunque susceptible de matización- herencia naturalista que puede detectarse tras lo erótico. "“Aproximación a la Historia de un escéptico, de Alberto Insúa", Mosaico de varia lección literaria, Universidad de Sevilla, 1992, pp. 331-354, p. 352-3).

${ }^{44}$ Fernando García Lara, "La novela erótica como arquetipo del modernismo literario ", AA. VV., El escultor Julio Antonio. Ensayos de aproximación. Tarragona, Diputación Provincial, 1990, p. 59.
} 
segundos se sirvieron de los trabajos de aquéllos para intentar proporcionar a sus obras el nivel analítico que exigieran los hermanos Goncourt a la novela moderna en el prólogo a Germinia Lacerteux y reclamara Edmundo en La ramera Elisa (1877):

"Mi hermano y yo escribimos hace trece años en el prólogo de Germinia Lacerteux: «Hoy que la novela se ensancha y extiende, que empieza a ser la forma grande, seria, apasionada y viva del estudio literario y social, que se convierte por el análisis y por la psicología en la historia moral contemporánea; hoy que la novela se ha impuesto los estudios y los deberes de la ciencia, puede exigir sus libertades y franquicias». En 1877 vengo a reclamarlas otra vez"45.

Entre otros ensayos disciplinares, ejercieron como fuentes literarias para abordar la temática sexual los trabajos de Harry Campbell (Differences in the Nervous Organization of Man and Woman, 1891), Edward Carpenter (Love's Coming of Age: A Series of Papers on the Relations os the Sexes, 1896), Havelock Ellis (Man and Woman: A Study of Human Secondary Sexual Characteristics, 1894) o Cesare Lombroso y William Ferrero (The Female Offender, 1899). Las tesis de Richard von Krafft-Ebing en su Psychopathia sexualis (1886) sobre la "inclinación instintiva [de la mujer] a la subordinación voluntaria del hombre", confirmada en la perversión masoquista propia del género femenino, sirvieron de fundamento "clínico" a una narrativa que convirtió en motivo habitual los malos tratos ${ }^{46}$. El prototipo de mujer sumisa y masoquista del arte de fin de siglo estaba confirmado por la ciencia y el servirse de estas situaciones era considerado muy "científico" en la novela de aquellos años.

Para el caso español las relaciones entre ciencia y erotismo naturalista son descritas por Max Aub como sigue:

"Un grupo de médicos forma la vanguardia de un numeroso grupo de novelistas más o menos pornográficos, que son pasto de muchos lectores y de la industria editorial, y que poco tienen que hacer en la historia de la literatura" 47 .

\footnotetext{
${ }^{45}$ Edmundo de Goncourt, La ramera Elisa, Madrid, Ágata, 1998, p. 3.

46 "De ahí, -según Dijkstra- que los ejemplos literarios de este deseo femenino se hiciesen legión, sobre todo en las obras de los seguidores de Zola y de los poetas simbolistas." Nana (1880), la protagonista del mismo nombre de la obra de Zola, disfruta siendo golpeada, y Concha, personaje principal de La mujer y el pelele (1898) de Pierre Louÿs, goza con espasmos de los ataques violentos de su amado, mientras él la apalea "con la regularidad con la que un campesino sacude un mayal". Véase el brillante trabajo de Bram Dijkstra, Ídolos de perversidad. La imagen de la mujer en la cultura de fin de siglo. Madrid-Barcelona, Debate-Círculo de Lectores, 1994, en especial p. 101s, de donde están tomadas las citas.
}

${ }^{47}$ Max Aub, Manual de historia de la literatura española, Madrid, Akal, 1974, p. 492. Para García Lara ("La novela erótica como arquetipo del modernismo literario", op. cit., p. 58), la "cuestión sexual" pasó en poco tiempo de ser motivo de interés científico a lo literario, de lo que son muestras primerizas las obras iniciales de Zamacois o la serie de López Bago sobre la prostitución. En ellas, como también en Trigo, se observa cómo el lenguaje científico se traduce e incorpora a la novela. Ello supone "el replanteamiento de la tradición sensualista y fisicalista que desde el siglo XVIII venía explicando la parcela de lo pasional y sentimental (recogida ahora por el cientifismo que la elabora como psico-fisiología)", pero también un interés "vitalista" desde el que se pretende "explicar la función del amor, de las pasiones, del sexo, de la familia", decisivo en la conformación del modelo de novela erótica. La burguesía quiere que "se le expliquen el amor y su valoración moral, social y científica de una manera nueva". 
Hoyos escogió, entre las distintas ramas que partieron de aquel interés común, la más tardía de la patología sexual femenina, explotada por el arte del expresionismo ${ }^{48}$ y que en la primera década del siglo venía refrendada por la convicción de que la mujer poseía un animal dentro y, aunque luchase contra esa bestia, acababa siempre por sucumbir a ella ${ }^{49}$. Pudo haberle servido de "coartada científica" la extendida tesis de Lombroso y Ferrero, en su estudio frenológico La mujer delincuente:

"Una actividad mórbida de los centros físicos intensifica las malas cualidades de las mujeres y las induce a buscar alivio en malas acciones; cuando la piedad y el sentimiento maternal están ausentes, y en su lugar aparecen fuertes pasiones y tendencias intensamente eróticas, desarrollando [...] una inteligencia superior para la concepción y ejecución del mal, es obvio que la potencial semicriminal que es la mujer normal se debe transformar en un criminal de hecho mucho más terrible que cualquier hombre"; sobre todo porque "las mujeres son niñas crecidas", con capacidad moral mínima, por lo que "sus tendencias malvadas son más numerosas y variadas que las de los hombres", y "cuando se despiertan y excitan, producen efectos proporcionalmente mayores"so.

Que Hoyos pretendía todavía en sus años finales usar el argumento de la ciencia para explicar los modelos de sus personajes lo demuestra el prólogo que pidió a Gregorio Marañón para la recopilación de Sangre sobre el barro [1934], en la que incluye El caso clínico y La procesión del Santo Entierro, dos de sus títulos más exitosos y cuyas protagonistas respectivas son casos claros de chocantes patologías sexuales. Las declaraciones de Simarro en 1917, cuando accedió a escribir el prólogo de El caso clínico, no debieron de ser la confirmación que el marqués esperaba a esta pseudosiquiatría literaria; Simarro había preferido desmarcarse de los juegos de ficción, quejándose de aquella aberrante impostura que hacía con tanta frivolidad de la ciencia material para la literatura; según él resulta

"vano empeño querer aquilatar el diagnóstico de las enfermedades imaginadas por los poetas [...]. El pretenderlo valdría tanto como querer explicar anatómicamente el centauro, la sirena o la esfinge". "La patología de la literatura, como la zoología de la fábula o la física del anillo de Giges [...] no tienen, ni presumen tener, un valor científico"s1.

Evidentemente, si Hoyos le había propuesto escribir aquel prólogo, era porque esperaba otro tipo de respuesta, y no contento con el resultado volvió a probarlo con Marañón en la reedición de la novela en 1934. Este otro doctor, más aficionado a la mixtura de lo literario y lo médico, ofrece a Hoyos la deseada justificación cuando elogia su "sagacísima valoración artística de lo patológico" o afirma que

\footnotetext{
${ }^{48}$ Véase las páginas de Bram Dijkstra sobre Paul Klee en Ídolos de perversidad, op. cit., p. 282.

${ }^{49}$ Bram Dijkstra, ibid.

${ }^{50}$ Cito por Dijkstra, ibid., p. 289.

${ }^{51}$ L. Simarro, prólogo a Hoyos y Vinent, El caso clínico; Madrid, Biblioteca Hispania, colección "Las novelas de la pasión", 1917, p. 9.
} 
"gran parte de sus creaciones artísticas [de Hoyos] están extraídas de la realidad nosocomial, o bien creadas, con certera adivinanza, sobre tipos patológicos exactamente ciertos. Así también los de esta serie de novelas"s2.

El naturalismo había expresado desde los Goncourt su interés por las patologías mentales, lo que en parte coincidía con la difusión de las lecturas de Freud ${ }^{53}$ y los intereses psicologistas de la novela del XX: Ortega defendía que a aquella cantera agotada de los temas novelescos le "quedan los filones secretos, las arriesgadas exploraciones en lo profundo", que serán las que le lleven a su materia más propia: la "psicología imaginaria"; y Baroja, en el "Prólogo casi doctrinal sobre la novela", afirma que "toda la gran literatura moderna está hecha a base de perturbaciones mentales" estos términos, Hoyos construye un museo de perversiones sexuales femeninas, verdaderas protagonistas de sus obras ${ }^{55}$. No es extraño que a Hoyos le interesen más las mujeres: el erotismo de fin de siglo considera la patología erótica de la mujer mucho más interesante y variada que la masculina. A eso debe añadirse que era la mujer la que había cambiado su papel social" y por tanto el personaje que se "estaba descubriendo" en los Estudios de psicología sexual de Havelock Ellis, en La cuestión sexual de August Forel o en las Lecciones sobre el hombre de Carl Vogt. Pero el que los personajes femeninos del marqués encuentren su explicación clínica en aquellos difundidos estudios, no ha servido para que la crítica, desde la que le hicieran sus contemporáneos hasta la actual, encuentre en ellos posibilidad alguna de indulto: para Cansinos, Hoyos

“es [...] especialista en la descripción de hembras lascivas, histéricas, anormales, ávidas de sensaciones raras e incapaces de amor, para las que el hombre es siempre el pelele de la novela de Pierre Louys"s7.

\footnotetext{
52 G. Marañón, prólogo a Sangre sobre el barro, ed. cit., p. 17.

53 Lily Litvak conecta la difusión de Freud con el interés por los temas sexuales e incluso con las nuevas tendencias sociales de liberación: "Se izó la bandera de la libertad sexual. Todos habían leído a Freud. Se descartaban inhibiciones y represiones [...] Estaba de moda ser blasé y creer en el amor libre." L. Litvak, introducción a su Antología de la novela corta española de entreguerras, Madrid, Taurus, 1993, p. 13.
}

${ }^{54}$ Ortega, Ideas sobre la novela, ed. de A. y G. Gullón, Teoría de la novela, Madrid, Taurus, 1974, pp. 29-64 y Baroja, "Prólogo casi doctrinal sobre la novela", La nave de los locos (ed. de Francisco Flores Arroyuelo; Madrid, Cátedra, 1987), que distingue sin embargo en aquel "pantano", "la ridícula perversidad, casi siempre industrial, de los escritores eróticos, [...] indudablemente habitado por monstruos extraños y sugestivos".

${ }^{55}$ Alfonso García, Antonio de Hoyos y Vinent, op. cit. p. 256: "es la personalidad de la mujer la que desencadena el conflicto -..., de modo que los hombres no hacen sino asumir el papel que les corresponde, dominado o dominador".

${ }^{56}$ Litvak estudia la convivencia de "cierto feminismo elegante y disipado" que se vive en los ambientes sociales, con la "lucha por la emancipación de la mujer" presente en España a través de asociaciones reivindicatorias como Asociación Nacional de Mujeres Españolas, Liga Española para el Progreso de la Mujer, etc. (Litvak, Antología de la novela corta española de entreguerras, op. cit., pp. 13-4). V. también Lidia Falcón, Mujer y sociedad. Análisis de un fenómeno reaccionario, Barcelona, Fontanella, 1969, pp. 181-4.

${ }^{57}$ Cito por Alfonso García, Antonio de Hoyos y Vinent, op. cit. p. 240. Carlos Fortuny (Álvaro Retana) califica los personajes femeninos de Hoyos de pura convención y argumenta que no podía ser de otra manera porque las inclinaciones sexuales de su autor no le llevaban a relacionarse con mujeres (Carlos Fortuny, La ola verde. Crítica 
Y sin embargo, cabe preguntarse hasta qué punto no encarnó su autor sus propios conflictos en torno a la culpa y la perversión en sus extraños monstruos femeninos, más que en los personajes masculinos. Hasta ahora los estudiosos de su novela han buscado siempre sus alter egos en el muestrario de varones, pero quizá valga la pena perseguirlos en figuras como la de la protagonista de El monstruo.

Si el naturalismo conecta a Hoyos con un grupo particular de autores del Novecentismo -el de los novelistas populares y el de los habituales del asunto erótico-, no puede olvidarse que puede servir también como punto de encuentro entre estas filiaciones y la que ha sido menos comprendida del autor: el anarquismo. Apuntemos por ahora que las doctrinas positivistas del naturalismo figuran como ingrediente fundamental de la ideología del anarquismo español; naturalismo, novela erótica y movimiento libertario comparten entre otras cosas las mismas lecturas: Zola, Mirbeau, Ibsen, por citar tres autores imprescindibles. En segundo lugar, la novela erótica participaba de cierto componente utópico que no puede considerarse irrelevante ${ }^{58}$.

\section{MODERNISMO}

Con el modernismo de Hoyos y Vinent, la crítica suele referirse al aspecto formal de su discurso ${ }^{59}$. De hecho, la labilidad de la etiqueta en la historiografía literaria ha favorecido que, sin muchas precisiones, acabe empleándose para caracterizar un determinado estilo de la expresión. Por lo mismo cabría analizar aquí la conexión de Hoyos al simbolismo, no entendido como movimiento literario, sino como "lenguaje general de la época"60; su propósito de unir las sensaciones de las artes tendría una versión particular en esa "prosa enjoyada" -por usar la expresión de Villena- que quiere ser al tiempo musical y plástica; de otro lado, la "transgresión de las pautas de la racionalidad artística y una apelación a la

frívola, Barcelona, Jasón, 1931, pp. 78-9). O bien no se mantuvo la amistad entre Hoyos y Retana hasta estas fechas, o bien éste le paga con mala moneda las muchas defensas que el primero había hecho de sus novelitas licenciosas y galantes en las reseñas de El Día. Es más probable lo primero, ya que en 1931 Hoyos y Vinent ha entrado ya en la senda del sindicalismo libertario y su actitud hacia la novela que él mismo cultivó es muy distinta (véase por ejemplo su columna "La «quinta columna" en la calle", El Sindicalista, n 409, 17 de septiembre de 1937, p. 4). Por otra parte, si es cierta la singular anécdota que recoge Javier Rioyo (cuando al concluir la guerra detienen a Retana en casa de un conocido asaltador de conventos y se le juzga acusado de haber bebido semen en cálices consagrados, él lo negó respondiendo: "Eso es falso, siempre lo he bebido directamente sin recipiente alguno"), Retana no hubiera podido tampoco construir buenos personajes femeninos por la misma razón que Hoyos -razón además tan peregrina como corresponde al título de sus ensayos frívolos-. Javier Rioyo, Madrid, Casas de lenocinio, holganza y malvivir, Madrid, Espasa Calpe, 1991, p. 334.

${ }^{58}$ García Lara, "La novela erótica como arquetipo del modernismo literario", op. cit., p. 59. También en su estudio sobre Felipe Trigo, (F. García Lara, El lugar de la novela erótica española, op. cit., pp. 98, 100 y 108) demuestra las filiaciones políticas del "padre" de los novelistas eróticos con el PSOE; desde el n 128 (17-VIII-1888) Trigo colabora con El Socialista con una serie de artículos que aparecen bajo el título Las plagas sociales y que se inician con la afirmación: "Propiedad privada: borrad esa frase de todos los códigos, y para siempre quedarán establecidas la justicia, la libertad y la fraternidad universales". Durante los años de estancia en Sevilla (92-93), Trigo utilizó para algunas de sus colaboraciones en El Posibilista el pseudónimo de Ravachol, célebre anarquista.

59 Recordemos la cita ya mencionada de L. A. de Villena sobre "la prosa del más enjoyado modernismo" característica del autor.

${ }^{60}$ Mainer, "La llamada generación del 98: otros puntos de vista", op. cit., p. 39. 
superioridad del arte sobre cualquier tipo de conocimiento físico o moral", que son "el fondo de toda estrategia simbolista" ${ }^{\text {, }}$, están también inconfundiblemente presentes en el estudiado esteticismo de nuestro novelista.

Pero la etiqueta quizá pueda servir también, aprovechándola en la variedad que le presta la interpretación de Ricardo Gullón, para explicar la particular asociación que establece aquel autor entre lo erótico y lo místico, y que constituía de hecho una de las "direcciones" del Modernismo que proponía Gullón en su ya clásico ensayo ${ }^{62}$.

Se ha mencionado que la temática erótica presenta en el caso de Hoyos un interés extremado por las perversiones patológicas; pero es la íntima e insólita conexión de éstas con lo religioso lo que aún en su época resultaba más chocante. La perversidad se anuncia como un ritual religioso, como un camino de ascesis en pos de la huidiza trascendencia, en una paradójica confluencia de estirpe baudeleriana que Hoyos lleva a extremos grotescos. La tensión entre lo sexual y lo religioso de la Salomé de Wilde y que tiene modelos hispánicos en el Rubén de "Ite, Missa est" o el primer Valle-Inclán (especialmente el de la colección Jardín umbrío), debieron ser punto de partida para la ilustración de la más lóbrega depravación en clave mística. Los más respetuosos con Hoyos de entre sus contemporáneos, queriendo salvarlo de la calificación degradante de pornográfico o erótico, recurren con frecuencia al análisis de esta extraña mixtura con ánimo de colocar las perversiones de sus novelas más allá del puro deleite escabroso. Así Benavente, en el prólogo a El martirio de San Sebastián (1917) explica:

\begin{abstract}
"Antonio de Hoyos [...] es un fuerte escritor que, de no atreverme a llamar místico, por no escandalizar, [...] yo llamaría, por lo menos, atormentado. Atormentado como los místicos, como los santos penitentes. Con ellos, él sabe cuánta es la pesadumbre del pecado sobre la luz espiritual, que en el más bajo y despreciable barro humano palpita temblorosa [...]; él sabe de celestiales asunciones en que la más baja criatura llega a confundirse con Dios, y de caídas abismadoras, en que los ángeles se hunden en las negruras del infierno [...] La obra de Antonio de Hoyos -...- es siempre religiosa, afirmación del Espíritu, de su divino origen, de su inmortalidad.
\end{abstract}

Antonio de Hoyos -...-, tal vez, -yo no lo creo- a pesar suyo, es un escritor místico, de un misterioso e intenso misticismo" ${ }^{\prime \prime 3}$.

Cansinos, tantas veces crítico con Hoyos, reconoce -contra la opinión de otros contemporáneos- que la relación entre sexo y muerte tiñe de valor ético las narraciones del marqués y permite entenderlas "como un intento de purificación" (él mismo había publicado en 1916 su Estética y erotismo de la pena de muerte. Estética y erotismo de la guerra que Hoyos reseñará muy elogiosamente en El Día $)^{64}$. Y mucho tiempo después,

\footnotetext{
${ }^{61}$ Mainer, ibid.

${ }^{62}$ Ricardo Gullón, Direcciones del modernismo, reed. en Madrid, Alianza, 1990.

${ }^{63}$ Benavente, prólogo a Hoyos, El martirio de San Sebastián: Novela. [Madrid], V. Rico, [s.a.] [1917], pp. 7-8.

${ }^{64}$ Cansinos-Asséns, Nueva Literatura IV, ed. cit., pp. 73-4 (sobre la reseña de Hoyos ver nota 68). No quiso verlo así, por ejemplo, Eduardo Gómez de Baquero, que responde con una reseña en La Época, (23 de agosto de 1920), titulada significativamente "Una novela ¿cristiana?", a las "Varias consideraciones y observaciones conducentes al
} 
Gregorio Marañón seguía aquel criterio en el prólogo a Sangre sobre el barro (1934) defendiendo la profunda moralidad del vicio que Hoyos muestra tan descarnadamente:

"Yo creo, por eso, en el sentido moral de estas trágicas almas [...] Su contemplación nos sirve de penitencia. [...] La realidad turbadora de estas páginas de nuestro gran novelista, nos hiere en el alma con una bofetada, y nos recuerda aquélla que la mano de nuestros abuelos daba en la cara de los pequeñuelos, ante el reo en garrote, para que le sirviese de recuerdo del crimen y de guía en el camino del bien"65.

Hoyos pretendió fomentar esa imagen que, por lo que demuestran sus críticas y reseñas, contaba con todas sus simpatías: sobre todo durante los años de la primera gran guerra le hubiera gustado ser como su admirado Valle-Inclán, a quien retrata como "poeta místico que tiene un alma en llama, el alma ardiente y visionaria que tuvo tal vez el Caballero de la mano al pecho"66. El alma mística que goza al tiempo de los placeres de una culpabilidad inevitable en su propensión a los más exquisitos goces de la carne es para Hoyos indicio cierto de modernidad y egregio refinamiento ${ }^{67}$. Pecado, culpa, deseos, placeres nefandos y una infinita sed espiritual se conjugan inextricablemente y su confluencia ofrece a su gusto magníficos resultados literarios. Así por ejemplo en la novela de Rodríguez Larreta, La gloria de don Ramiro, de la que elogia ese

"misticismo doloroso y enfermizo, una voluptuosidad, a veces acre, a veces delicuescente, que tiene siempre del pecado cristiano y del concepto oriental del placer, ${ }^{68}$.

Santidad y pecado alternan en los lemas que inauguran los capítulos de sus novelas, costumbre muy característica de Hoyos, sobre todo en su primera época: si una de las máximas procede de Santo Tomás, desde la siguiente le responde el marqués de Sade.

Es importante recordar que en el capítulo que dedica a "Los eróticos" de La nueva literatura, Cansinos Assens no incluye a Hoyos en ninguna de las tres modalidades que él distingue en aquel grupo de escritores (novela licenciosa, novela galante de estirpe francesa

perfecto esclarecimiento de lo que va a leerse después", prólogo de Hoyos a Las lobas de arrabal, y donde argumentaba ser el suyo un "libro cristiano en su triple concepción del amor, de deseo y de la voluptuosidad." Para Ardenio la obra de Hoyos es sólo una pesadilla sin tesis, ni siquiera de religiosidad a la manera decadente y preciosista de Huysman, sino pura degeneración amoral (Alfonso García, Antonio de Hoyos y Vinent, op. cit., p. 181).

${ }^{65}$ G. Marañón, prólogo a Sangre sobre el barro, ed. cit., p. 19.

${ }^{66}$ Hoyos, "Una fiesta de fraternidad literaria”, El Día, n 13.192, 18 de diciembre de 1916, p. 6.

${ }^{67}$ De ahí que una de las tipologías preferidas de Hoyos para los personajes masculinos traslade al varón la modernista de la mujer mística y ardiente, en un equívoco juego de transposición de géneros muy de su gusto; aquel mito finisecular de la virgen frágil y espiritual se encarna por ejemplo en el afeminado Silvio de El crimen del fauno (ed. de Rosario Ruiz Rubio, Madrid, Emiliano Escolar, 1980), "turbado por místicas inquietudes, abrasado de raros ardores, enfermo de incurable melancolía" (p. 49), cuyas palabras de amor eran como la "letanía [..., versos llenos de místico deliquio de los áridos santos españoles que se abrasaron de amor" (p. 78) y que, muerto al final, se compara a un "mártir de marfil" (p.140).

${ }^{68}$ Hoyos, "Obras y figuras/ Un retrato de Rodríguez Larreta, por Ignacio Zuloaga", El Día, n $13.187,12$ de diciembre de 1916, p. 1 . 
y novela erótica como denuncia social). Nuestro autor ocupa en solitario una categoría que Cansinos llama la del "amor monstruoso", pues el suyo es un erotismo que se presenta como "anhelo extraño", "fobia que inquieta y atormenta" y que escoge "toda esa parte negra de la liturgia sexual" que, como herencia de Lorrain y de D'Annunzio pero también del simbolismo erótico de Louys o Wilde, asocia el sensualismo y la voluptuosidad con la muerte $^{69}$. De hecho en Hoyos el tema sexual, lejos de representar ameno entretenimiento en las tramas, está asociado a lo irracional, al horror y el miedo, al crimen y la disolución hasta el punto que el propio Hoyos reconoce que en sus libros "no hay voluptuosidad ninguna en mis libros el amor es una cosa horrenda y escalofriante" . Entronca con ello con esa literatura del mal en la que, como explica Bataille,

"Tanto si se trata de erotismo puro (...) como de sensualidad de los cuerpos, la intensidad es mayor en la medida en que se vislumbra la destrucción, la muerte del ser. Lo que llamamos vicio deriva de una profunda implicación de la muerte. Y el tormento del amor desencarnado es tanto más simbólico de la verdad última cuanto la muerte aproxima y hiere a aquellos a los que el amor une"r1.

A este erotismo enfermizo y perverso sirve de escenario una estética de lo lúgubre, lo marginal, lo brutal y lo miserable, vías todas que se exploran en la necesidad de escapar de la vulgaridad y que concluyen siempre en la aniquilación. Estamos viviendo el ritual de la aventura hacia la disolución que probó el erotismo de Baudelaire en las Flores del mal, avanzadilla de todas las exploraciones simbolistas y modernistas en esa escala invertida de "Grados ad Parnasum", en cuyo descenso la perversidad adquiere categoría de ascesis". Como en la vía mística, aunque en dirección contraria, también en este caso se procede a una destrucción, una negación del Yo, necesaria para alcanzar el verdadero Yo superior, para confirmar en el quebranto de los límites que tras ellos nos aguarda el infinito: mientras se puedan sentir las fronteras es que existen las posibilidades de un más allá. Y al lado del dandismo, el alcohol y las drogas, el sexo funciona como otra forma de negación del Yo por la maldad (baste recordar aquella afirmación de Mi corazón al desnudo: “¿Qué es el amor? La necesidad de salir de uno mismo"733).

${ }^{69}$ Cansinos Assens, La nueva literatura II. Las Escuelas, ed. cit., pp. 210-211. Si en La Nueva Literatura, (op. cit., p. 211) había querido diferenciar el erotismo de Trigo del de Hoyos ("al gesto claro con que en las obras de Trigo proclaman hombres y mujeres su derecho a enlazarse normalmente [...] añade Hoyos el gesto vago y turbio de los que sólo aspiran a enlaces parciales e incompletos y a miserables alegrías"), en Poetas y prosistas del novecientos (Madrid, América, 1919, p. 230) los opone: "la obra de Felipe Trigo es una larga campaña contra los prejuicios sociales, la obra de Hoyos es la glorificación estética del pecado". El propio Hoyos al reseñar en El Día la Estética y erotismo de la pena de muerte. Estética y erotismo de la guerra (1916) de Cansinos-Asséns, exclama: "¡Cómo dudar que la lujuria y la muerte son hermanas! [...] El amor sin la muerte es incompleto. Hay en el amor [...], una lascivia triste y desesperada, que desagua en la muerte, como en la muerte hay una excitación que puede llegar hasta el placer" (Hoyos y Vinent, "Libros de la semana. Estética y erotismo de la pena de muerte", El Día no 13.306, 11 de abril de 1917, p. 3).

${ }^{70}$ Entrevista de José María Carretero a Hoyos en La Esfera, 5 de mayo de 1916, op. cit.

${ }^{71}$ Bataille, La literatura y el mal, Madrid, Taurus, 1987, p. 22-3.

${ }^{72}$ Félix de Azúa, Baudelaire y el artista de la vida moderna, Barcelona, Anagrama, 1999, p. 59.

${ }^{73}$ El resultado de la investigación baudelaireana, explica Azúa, concluye en un callejón sin salida: "Las callejas de 
La conocida declaración de Baudelaire (“ $¡ A y$, los vicios humanos! Son ellos los que contienen la prueba [...] de nuestro amor por el infinito") es la única desde la que se puede explicar la defensa que hace Hoyos y Vinent de la espiritualidad de sus perversiones narrativas ${ }^{74}$. Resulta por eso extraño que la crítica hasta ahora no haya apenas sino apuntado marginalmente la presencia de Baudelaire en la obra del novelista español, cuando además el propio autor deja constancia de sus lecturas del francés al usar con frecuencia citas frecuentemente en el original francés- del poeta maldito ${ }^{75}$. El mismo Hoyos nos obliga a conectarlo con su precedente cuando se dirige al lector en la dedicatoria a El árbol genealógico (1918); como lo pedía también el "Epígrafe para un libro condenado" con el que se cierran Las flores del mal, allí exige que se lea su novela desde la personal negación de la normalidad:

"habéis de leerlo con el pío recogimiento con que leeríais un «Tratado ascético de la Lascivia y de la Muerte».

Si no, no sigáis adelante."

La curiosidad científica naturalista por los asuntos sexuales ha acabado, espiritualizada por el modernismo, ofreciendo a la narrativa erótica las posibilidades de una argumentación mística. Hoyos es consciente de ello cuando explica que

"el espanto trágico de la vida sexual ofrecióme, como en su libro La tentación de san Antonio dice Flaubert, infinidad de facetas o variedades. Por un lado lindaba con la biología, por el otro con la metafísica"’n6.

En este apartado sobre el modernismo de Hoyos tiene también cabida el análisis de su filiación con uno de los teóricos más citados y respetados por el autor en sus reseñas literarias, John Ruskin. Antes de que su nombre se convirtiera en autoridad habitual entre los teóricos españoles -lo que sucede, según Fernández Cifuentes, después de la primera

la Ciudad del Mal muestran, al cabo, su banalidad. Satanás, que antes parecía encarnar la Salvación, aparece ahora en toda su desconsiderada vulgaridad", "se encoge ahora de hombros, muestra las palmas de las manos y alza las cejas como diciendo: lo siento, hijo mío, se me han acabado los trucos. Satanás decepciona" (Azúa, Baudelaire y el artista de la vida moderna, op. cit., p. 67). Es la misma desolación con que concluyen todas las aventuras de Hoyos.

${ }^{74}$ Defensa que hizo directamente, o bien a través de sus personajes: en Las lobas de arrabal, uno de los alter-ego de Hoyos, Lorenzo Álvarez de Salazar, escritor fascinado por la abyección y la miseria, se nos presenta como un místico en los oscuros afanes de su alma laberíntica: "Su misticismo era un monstruoso disfraz de fraile poseído del Demonio, debajo del que cabían todos los pecados y todas las abominaciones" (Las lobas de arrabal: Novela. Madrid: V. Rico, [s.a.,1920], p. 99).

${ }^{75}$ Es Luis Antonio de Villena, sobre todo en "Antonio de Hoyos y Vinent, la pose y la decadencia" (Corsarios de guante amarillo. Sobre el dandysmo, Barcelona, Tusquets, 1983, pp. 113-121), quien más se ha detenido en esta relación a la que Antonio Cruz Casado ("Modernismo y parodia en la narrativa de Antonio de Hoyos y Vinent", El Modernismo español e hispanoamericano, Córdoba, Diputación Provincial, 1987, 399-407) sólo hace breve alusión.

${ }^{76}$ Hoyos y Vinent, prólogo a América. El libro de los orígenes, Madrid, Sociedad Gral. Española de Librería, 1927, pp. 6-7. 
guerra mundial" la estética". Lo seguirá siendo para él durante los años en los que colabora con El Día, desde cuyas columnas demuestra conocer bien las tesis del inglés, tanto en lo que se refiere al poder del arte para reflejar "una vida misteriosa, una vida que está «más allá de la vida que vemos», una vida que es «como un reflejo de la vida interior»", como en la necesidad de evitar que el sistema capitalista de mercado se enseñoree de la creatividad:

"sin un mercantilismo que espolee la voluntad [...], la obra [de arte] es más íntima, más espiritual, más intensa, tiene algo de misterioso rito religioso en que el artista como un sacerdote ofrenda toda su alma"7s.

Al considerar la adhesión de Hoyos a los juicios teóricos de Ruskin, no puede olvidarse que la "Pre-Raphaelite Brotherhood" nace en el Londres de 1848, más que como tendencia pictórica, como un "último brote romántico" cuyas preocupaciones sociales le conducen a dictámenes sobre el arte más allá de lo puramente estético. Cerdá i Surroca los presenta como un grupo de conspiradores subversivos, enfrentado no sólo al establishment artístico, sino también al socioeconómico: "muy en síntesis, representan los opósitos de una aristocracia del espíritu regida por Hermes, frente a otra aristocracia mercantil regida por Mercurio" 79 .

En segundo lugar, el "sistema de percepción y contemplación" de la belleza que propone Ruskin no proporciona sólo un placer accidental, sino que implica la naturaleza moral del hombre: al convertir el arte en religión lo eleva al plano moral en cuanto que "una respuesta adecuada a la belleza sensible debería llevar a una aprehensión religiosa del universo" ". La teoría de Ruskin acababa orientándose hacia tesis socioeconómicas al plantear que dicho arte-moral conduciría a una actitud de cooperación de la que nacerían mejoras sociales. Esta fue la doctrina que difundió en sus conferencias de los años 80 sobre la relación arte-sociedad y en las que desde un vitalismo provocador, reaccionaba contra la comercialización industrial del arte burgués y a favor del artesano. Por esos mismos años su camarada William Morris, el otro gran teórico del grupo, simultaneaba su compromiso con la estética moral y su militancia socialista (su Art and Socialism es de 1884).

Ruskin y Morris se difunden en el Madrid de la primera década del siglo XX, cuando $L a$ España Moderna edita en 1906 algunas obras traducidas por Ciges Aparicio (sobre todo las que tratan de temas sociales) y el mismo año Edmundo González-Blanco saca una antología de Ruskin, Obras escogidas. Son justamente estos los años de formación de Hoyos, que mantendrá durante mucho tiempo al teórico inglés entre sus autoridades estéticas. Algo del pensamiento prerrafaelista puede perseguirse en la filiación que Hoyos propone entre lo

\footnotetext{
${ }^{77}$ Fernández Cifuentes, Teoría y mercado de la novela, op. cit., p. 136.

${ }^{78}$ Hoyos y Vinent, "Obras y figuras/ el arte maravilloso de Romero de Torres", El Día, n 13.178, 3 de diciembre de 1916, p. 4. Ver también sus reseñas de El Día, no 13.216, 11 de enero de 1917, p. 3; o la que dedica a "El arte de los hermanos Zubiaurre", El Día, n 13.269, 5 de marzo de 1917, p. 3.

79 María Ángela Cerdá i Surroca: "Influencias inglesas en la génesis del Modernismo: Ruskin y Morris", El Modernismo español e hispanoamericano, Córdoba, Diputación Provincial, 1987, 53-68, p. 54.

${ }^{80}$ Ibid.
} 
artístico, lo religioso y lo político, las tres claves de su poética y que más adelante marcará como sucesivas etapas de su trayectoria ${ }^{81}$.

\section{VITALISMO. EL DEBATE SOBRE EL REALISMO.}

Frente a naturalismo y modernismo, el elemento que ahora observamos no suele tener cabida entre las denominaciones de la periodología, pero forma parte fundamental del crisol literario de Hoyos, combinándose con los rasgos anteriores y dando razón de las convicciones más insistentemente declaradas de su poética personal.

Por vitalismo se entiende la corriente que parte del individualismo de Max Stirner, y su conocida máxima de El único y su propiedad (1845): "Para mí, nada existe por encima mío", posición que le sirviera para proclamarse enemigo radical del estado y la religión en todas sus formas y para hacer de los deseos personales fuente de toda libertad. Desde una perspectiva que comparte muchos ingredientes con los planteamientos románticos, Stirner no acepta más soberanía que la del individuo, el Único, suprema y absoluta realidad: sólo son respetables la fuerza individual y las pasiones y toda norma objetiva que las coaccione debe ser eliminada. Interesa resaltar desde ahora que Stirner fue un precedente importante de la vía individualista del anarquismo intelectual y referencia ideológica del movimiento libertario español, el primero en conocer sus críticas radicales a las convenciones sociales y que lo difundiría en nuestro país ya a finales del siglo XIX.

La influencia de Stirner entronca y continúa su difusión aliada con la de Nietzsche, el otro gran pensador del vitalismo que, según el clásico estudio de Sobejano, comienza a dejar sentir su presencia en las letras españolas en los primeros años del siglo $\mathrm{XX}^{82}$. Ambos, bien como fuentes directas o a través de sus muchos divulgadores, fueron nombres habituales de la literatura finisecular hasta el punto de que, como comenta Mainer, las ideas maestras de Nietzsche "conocieron una extraordinaria divulgación europea y española en el fin de siglo: cualquier redactor de un periódico de tercera fila podía considerarse un übermensch desconocido y cualquier poeta de provincias sentirse afligido por el «eterno retorno» de las cosas" ${ }^{\prime 3}$. En particular, cierto sector del movimiento simbolista, encabezado por Rémy de Gourmont, hizo de las tesis nietzscheanas estandarte novedoso para el

\footnotetext{
${ }^{81}$ Lo hace en clave literaria en un cuento de los años 30 titulado "La oscuridad", publicado en La Esfera $\left(\mathrm{n}^{\circ} 853\right.$, 10 de mayo de 1930) y luego en el volumen El seguro contra naufragio; también describe esa línea que le lleva de lo estético a lo místico y lo político en el prólogo a América. El libro de los orígenes (1927).

82 Sobre Stirner en España, R. Pérez de la Dehesa, "Introducción" a Federico Urales, Evolución de la Filosofía en España, Madrid, Novelas y Cuentos, 1967, p. 20. Gonzalo Sobejano, Nietzsche en España, Madrid, 1967, pp. 6782. Algunas de las afirmaciones de Sobejano sobre la presencia de Nietzsche en España fueron matizadas por José Álvarez Juncos en su Ideología política del anarquismo español (1868-1910), Madrid, siglo XXI, 1976, pp. 139 y 146-148. La adaptación del pensamiento de Stirner y Nietzsche a la ideología ácrata la ha estudiado recientemente Arno Münster: "Le Moi, l'unique et le néant: Nietzsche et Stirner. Enquête sur les motifs libertaires dans la pensée nietzscheenne", Revue Germanique Internationale 11 (1999), pp. 137-55 y 243-44.

${ }^{83}$ Mainer, "La llamada generación del 98: otros puntos de vista", op. cit., p. 39. Entre los autores en los que más se ha estudiado la influencia del vitalismo se cuentan Pío Baroja y Maeztu. Pero también Miró: Vicente Ramos, "El vitalismo mironiano" (en Ricardo Landeira (ed.): Critical Essays on Gabriel Miro. Lincoln, Society of Spanish \& Span-American Studies, 1979, pp. 13-16.
} 
modernismo, al tiempo que se servía de ellas para defender un anarquismo individualista que tuvo espectacular acogida en la intelectualidad ${ }^{84}$.

Precisamente el radicalismo de este principio individualista fue el que resultó más atractivo a intelectuales y artistas que en el fin de siglo se acercaron al movimiento libertario y en general a las posiciones de los escritores individualistas: Ibsen, Carlyle o Hauptmann, de gran importancia en los medios ácratas. Aunque ciertos sectores menos entusiastas preferían a la moral individualista de Stimer y Nietzsche la solidaria, sentimental y humanitaria de Kropotkin o Feuerbach, ya Sanz y Escartín en su famosa conferencia "Federico Nietzsche y el anarquismo intelectual" de 1902, considera que Nietzsche y anarquismo tienen importantes coincidencias que comparten con el Modernismo: el desprecio por los valores morales cristianos y el intento de fundar una nueva ética y una nueva estética sobre bases estrictamente humanas y naturales. Con Sanz y Escartín también la joven intelectualidad que se acercó al movimiento libertario y colaboró con sus órganos de prensa entiende que es la línea nietzscheana la verdaderamente anarquista. Sin embargo, Nietzsche empezó a ser combatido muy pronto por un amplio grupo de los libertarios desde la convicción, defendida por Federico Urales, de que este "pesimista enfermo [... fue] bueno para demoler, [pero] apenas si sabía edificar" mucho tiempo la actitud ambigua hacia el filósofo alemán propició varios debates: según Siguán, todavía en 1925 La Revista Blanca vive una polémica en sus páginas entre Federico Urales y Juan Grave sobre el individualismo ${ }^{86}$.

La presencia de Nietzsche en Hoyos es constante, tanto en lo que se refiere a su obra narrativa como, sobre todo, en sus artículos de prensa, en los que se convierte en una referencia habitual; al fin y al cabo, si debemos creerle, fue una de la lecturas en las que se formó ${ }^{87}$. Si el Nietzsche que aprovecha para sus crónicas políticas es el analista de la decadencia, en las novelas el que le interesa es el batallador de la moral del bienestar, el que afirmara en El caso Wagner (1888) que la moralidad niega la vida ${ }^{88}$, y por cuya autoridad

\footnotetext{
${ }^{84}$ Pierre Aubery: "Anarchisme des littérateurs au temps du symbolisme", Le Mouvement Social, no 69 (1969), pp. 21-34. Sobre el vitalismo como ingrediente del movimiento modernista, recordemos que Mainer, defendiendo la posibilidad de aplicar el término a autores en propio críticos con el modernismo, como Unamuno o Maeztu, recuerda que "cuando achacaban a los modernistas una naturaleza feble, una inspiración extranjerizante o anémica y unas obras vagas e indefinidas, hablaban en nombre de otro modernismo, el de la vitalidad y la energía, el de la vuelta a lo natural y espontáneo. Y tan modernistas eran los unos como los otros." Mainer, "La llamada generación del 98: otros puntos de vista", op. cit., p. 37.

${ }^{85}$ F. Urales, Suplemento de La Revista Blanca, 1900, $\mathrm{n}^{\circ}$ 68. Cito por Álvarez Junco, Ideología política del anarquismo español, op. cit., pp. 156-7.

${ }^{86}$ M. Siguán, Literatura popular libertaria, op. cit., p. 19.

${ }^{87}$ Hoyos, "El poeta de la Revolución", El Sindicalista n 271, 13 de abril de 1937, p. 4: cita los grandes autores de su primera época, cuando "éramos todos rebeldes y modernistas"; son Nietzsche e Ibsen, al lado de Rubén, ValleInclán, Azorín y Baroja.

88 "Hat man sich für die Abzeichen des Niedergangs ein Auge gemacht, so versteht man auch die Moral, -man versteht, was sich unter ihren heiligsten Namen und Wertformeln versteckt: das verarmte Leben, der Wille zum Ende, die große Müdigkeit”. Nietzsche, „Vorwort“ a Der Fall Wagner, Das Hauptwerk IV, München, nymphenburger, 1990, p. 179.
} 
los personajes de Hoyos, fascinados por el vicio, pueden argumentar que la moral es "algo propio de esclavos, innecesario cuando se tiene talento"s9.

Pero más allá de esta presencia directa que requeriría un estudio pormenorizado -como en el caso de Baudelaire, tampoco Nietzsche ha sido estudiado entre las fuentes de Hoyos-, las doctrinas del vitalismo nos importan porque sirvieron de base teórica para el debate sobre el realismo, que es también el debate fundamental de la estética ácrata ${ }^{90}$. Según Fernández Cifuentes, "toda la vida literaria española de la época giró en torno a esta inagotable polémica" "1; el ambiguo concepto de realismo, aplicado entonces a las fórmulas narrativas decimonónicas, debía para unos ser del todo rechazado (Ortega), para otros se mantenía en plena vigencia (Blasco) y un tercer grupo abogaba por una renovación (Pérez de Ayala $)^{92}$. En este contexto tiene un papel importante la poética vitalista por lo que pudo significar de renovador apoyo a las tesis del realismo, sobre todo en la versión defendida desde Prometeo entre otros por Gómez de la Serna. Confirmado por la autoridad de vitalistas como Anatole France, Gourmont u O. Wilde -presencias fieles de su revista-, Ramón defiende con Nietzsche la necesidad y la obligación del arte de comprometerse con la vida ${ }^{93}$.

Sus posiciones son compartidas, con matices muy diversos, por una larga nómina de críticos para los que la solidaridad de la novela con la vida se convierte en argumento cardinal de la teoría narrativa. Puede ser ejemplo la declaración de Ramón Tenreiro -crítico primero en La Lectura y después de la Revista de Occidente- al reseñar una novela de Ricardo León en 1909: “No sé encontrar en mi tintero más que un único elogio. Este libro, escribo, es como la vida" ". Al declararse "partidario de un vago realismo que se tenía por nuevo", Tenreiro, según concluye Fernández Cifuentes, demuestra una actitud representativa del conjunto de la crítica; la recurrencia a los dictados de ese realismo fue categoría habitual en las consideraciones sobre la novela, suponiéndose que participaba de una tradición española que lo autorizaba positivamente y que imponía al autor la observación minuciosa de su entorno. El concepto, sin embargo, no dejaba de ser bastante

\footnotetext{
${ }^{89}$ Es frase de uno de los alter-ego de Hoyos, Lorenzo Álvarez de Salazar, en Las lobas del arrabal, op. cit.

90 "La estética ácrata gira en torno de las relaciones del hombre con la realidad, y especialmente al considerar el arte como forma específica de la conciencia social". L. Litvak, Musa libertaria. Arte, literatura y vida cultural del anarquismo español (1880-1913), Barcelona, Antoni Bosch, 1981, p. 287.

${ }^{91}$ Fernández Cifuentes, Teoría y mercado de la novela, op. cit. p. 160.

92 Así Pérez de Ayala en Las máscaras (Madrid, Calleja, 1919, vol. I, p. 257), cuando afirma que "La creación artística no se concibe que sea una copia de la realidad exterior, ni la realidad artística es tal realidad por doblarse meticulosamente a imitar la realidad exterior [...]. Para juzgar a la realidad de una obra no necesitamos cotejarla con el modelo".

93 Véanse las páginas que dedica Matei Calinescu a la poética vitalista de Nietzsche: Cinco caras de la modernidad. Modernismo, Vanguardia, Decadencia, Kitsch, Posmodernismo. Madrid, Tecnos, 1991, pp. 185-186.

${ }^{94}$ Fernández Cifuentes, Teoría y mercado de la novela, op. cit., p. 40.
} 
vago 95 : parece que para Tenreiro ser como la vida significa no ser idealista (condición que le criticaba a Felipe Trigo), no crear a partir de la lectura, sino de la realidad vivida.

En el entorno de los novelistas populares, las exigencias de este realismo se hacían más intensas: Zamacois usa como reclamo publicitario para sus novelas el haberlas vivido previamente, incluyendo para ello "semanas en la cárcel, largos viajes en las máquinas de los trenes, noches en capilla con los condenados a muerte" ${ }^{\text {"96 }}$. Pero incluso Pérez de Ayala, según cuenta Juan Ramón Jiménez, "confesó haberse ido a vivir a una casa de prostitución, llevándose un baúl cargado de ropa, pues el estudio de tal ambiente le llevaría cierto tiempo"9?.

También Prometeo, como ya se adelantaba, se demuestra favorable a este tipo de novela. En "El concepto de la nueva literatura" (1909), Gómez de la Serna señala con convicción casi belicosa que "la nueva literatura tiende a ser lo menos literaria posible": si en el periodo inmediatamente anterior, y al ir acercándose a la burguesía, había ido aislándose de la realidad, ahora sólo le cabe volver a ser social, pues "es todo lo que hace falta". Menciona como origen de esta nueva posición en primer lugar a Nietzsche y Stirner, pero también a Gorki o Ernst Haeckel y afirma que "la primera influencia de la literatura es la vida, esta vida de hoy", y el resultado de la misma, el actual realismo subjetivo o, como él le llama, individualista. Dicho estilo realista se diferencia del tradicional porque quiere prescindir de lo usual para desenterrar "el verdadero concepto de la vida". Esos criterios servirán a Ramón y su grupo para defender desde la revista a Felipe Trigo o a Oscar Wilde que aunque no tenía tanto de social, sí de opositor a la norma social filistea. Fernández Cifuentes relaciona muy oportunamente esa versión de la «vida» con lo que entonces se llamaba, utilizando a Nietzsche con cierta trivialidad, lo dionisíaco, lo rebelde, perspectiva que permitía ver lo cotidiano, la realidad, con otros ojos que no fueran los de la mansedumbre de lo establecido ${ }^{98}$.

Sin embargo, aquella poética nietzscheana y vitalista podía para los menos perspicaces confundirse con la dependencia de la novela popular de las antiguas directrices del realismo decimonónico que, como en los consejos de El libro de cómo se hacen todas las cosas (1919) sobre cómo hacer una novela, proponía lograr que el lector pensara: “Parece que lo estoy viendo!". O en los casos más felices, servir como fundamento a un nuevo realismo que consistía, según Gómez de Baquero, en la "tendencia a conservar el realismo como elemento genérico de la novela, y a agregarle algún otro elemento... psicología, ocultismo, palpitaciones sociales, fondo histórico" 99 .

\footnotetext{
95 Ortega se lamenta en 1912 de que "el realismo español es una de tantas vagas palabras con que hemos ido tapando en nuestras cabezas los huecos de las ideas exactas." (cito por Fernández Cifuentes, ibid., p. 41).

${ }^{96}$ Ibid.

${ }^{97}$ Ibid., p. 42, que toma la anécdota de Alberti en La arboleda perdida.

${ }^{98}$ Ibid., p. 45.

${ }^{99}$ Ibid., pp. 177 y 54.
} 
Hoyos, colaborador él mismo de Prometeo y fiel siempre a Ramón ${ }^{100}$, demostró por extenso su fe en el realismo vitalista a través de sus reseñas literarias, especialmente en los comentarios de "Los libros de la semana" que publicó en El Día durante la primera guerra mundial. Usa en ellas como criterio nuclear la necesidad de la narración de ser producto vivencial y trasmitir a los lectores la imagen de la vida. A veces parece que su concepción personal de ese realismo coincide con la dionisíaca de Ramón, en cuanto espera de aquel arte la manifestación de una perspectiva verista que contraste con la cansina normalidad. Pero lo que resulta más interesante es que, en actitud contradictoria con la tendencia de su propia obra creativa y usando afirmaciones en las que parece estar dándose lecciones a sí mismo, critica, como había hecho Gómez de la Serna y el vitalismo en general, la novela literaturizada, aquella que toma de los libros y no de la vida sus asuntos y personajes. Así por ejemplo, el mayor defecto de Felipe Sassone es "un exceso de literatura espiritual":

"En la vida del señor Sassone hay demasiada literatura, «se mira vivir» demasiado, y no sólo en sus amores sentimentales, sino en sus momentos de lujuria, no sabe olvidar que escribe novelas". Esta enfermedad de la literatura, que nos es común a muchos, padécela en alto grado Manuel Amalfi [el protagonista de la novela]"101.

Y unos días más tarde, cuando reseña El baile de los espectros de José Mas, le aconseja que abandone todas aquellas perversidades necrofílicas tan pueriles:

“ipor qué, pues, no «vive de verdad», no observa la realidad y no olvida toda la literatura de aluvión de la que está saturado?"102.

Por la misma razón que había guiado a Gómez de la Serna y otros colaboradores de Prometeo, defiende también a Felipe Trigo: de la póstuma En camisa rosa elogia su "gran sensación de vida real" y ell estar "desposeída del fárrago de vanas literaturas y de filosofías alambicadas. Es sencillo, vivido, real"; y de En mi castillo de luz, del mismo autor, alaba "un perfume de realidad extraordinario, un encanto de «cosa vivida»"103. Frente a la reseña muy favorable de la Volvoreta de Fernández Flores ("Volvoreta es la vida misma; no hay en ella ni gestos teatrales, ni truculencias, ni descripciones superpuestas, ni filosofías traídas por los pelos") ${ }^{104}$, Wilde aparece criticado como "poseur atroz, un poseur genial, pero poseur al fin y al cabo. Todo su afectado desdén por la literatura fue una comedia, pues [...] su vida entera fue literatura" ${ }^{105}$. El mismo planteamiento le conduce, en el terreno de las

\footnotetext{
100 "el admirable funámbulo de la paradoja, el escritor interesantísimo que sabe saltar de una idea a otra como los Hanloons-leés saltaban de uno a otro trapecio". Hoyos y Vinent, "Una fiesta de fraternidad literaria", El Día, n 13.192, 18 de diciembre de 1916, p. 6.

${ }^{101}$ Hoyos y Vinent, reseña a La espuma de Afrodita, "Los libros de la semana", El Día, n 13.236, 31 de enero de 1917 , p. 4.

${ }^{102}$ Hoyos y Vinent, "Los libros de la semana", El Día, n 13.243, 7 de febrero de 1917, p. 4.

${ }^{103}$ Hoyos y Vinent, “Los libros de la semana”, El Día, n 13.250, 14 de febrero de 1917, p. 3.

${ }^{104}$ Hoyos y Vinent, "Libros de la semana”, El Día, n 13.285, 21 de marzo de 1917, p. 6.

${ }^{105}$ Hoyos y Vinent, "Libros de la semana", El Día n 13.335, 10 de mayo de 1917, p. 6. Parece aquí compartir Hoyos el criterio de Pérez de Ayala que criticara a Wilde la falta de un "concepto preciso del mundo y hondo sentido de la vida", además de verdadera simpatía humana con que vivificar a sus personajes (Perez de Ayala, Las
} 
artes plásticas, a criticar a Klimt como amanerado, prefiriendo a Romero de Torres, Zuloaga, o incluso los ensayos expresionistas, porque éstos, con técnicas muy diferentes, son expresiones vitales y no puro juego estético ${ }^{106}$. De nuevo desde criterios que resultan chocantes si pensamos en el tipo de novela que practica por aquellos años, defiende por ejemplo al escultor Rafael Vela porque en su obra

"no hay nada de esos eufemismos decadentistas que buscan una inquietadora ambigüedad en las figuras, que estilizan hasta el malestar. Todo es fuerte, sano, verdadero"1107

Por esa correspondencia que cierta crítica hizo entre vitalismo y realismo en su concepción tradicional a la que se hacía antes referencia, el patrocinio de la literatura vivida le lleva a Hoyos en no pocas ocasiones a defender los autores del realismo decimonónico por encima de las fórmulas de ese realismo fragmentario y que buscaba en la sorpresa y la novedad los cauces de la renovación: la literatura realista tradicional es merecedora de todos los elogios porque es vivida:

'Y es que la vida, cuando realmente el artista posee el don de sugerirla, es apasionante sobre toda ponderación y resultando tal vez más difícil interesar con narraciones del vivir cotidiano, cuando realmente se acierta con ello, no hay drama más extraordinario de horror o de pasión que pueda comparársele"108.

Esta nueva demostración de las diferencias entre la opinión crítica de Hoyos y su actividad creativa nos lleva a considerar el particular realismo de su narrativa, una vez apurada la evolución (desde las posiciones realistas y naturalistas de sus primeros trabajos a una fórmula simbolista en la que la realidad se ve sustituida por idealizaciones, visiones

máscaras, op. cit., p. 33-4). Sin embargo, se aparta con esta opinión del criterio del vitalismo entendido a la manera ramoniana. Probablemente no debía sentir Hoyos y Vinent gran simpatía por Wilde, a pesar de compartida afición a las demostraciones de dandismo, entre otras características comunes. Aunque Wilde no faltaba -ni podía faltar- en su biblioteca, (según certifica la entrevista que le hace El Caballero Audaz, op. cit.), son frecuentes las ocasiones en las que se muestra hostil con el inglés: como muestra valga el que uno de los cuentos incluidos en Vidas arbitrarias (publicado antes en La Esfera, $\mathrm{n}^{\circ}$ 264, 18 de enero de 1919) se titula "Una mujer sin importancia. Historia que nada tiene que ver con la mediocre comedia de Wilde". En La hora española. Ensayos (Madrid, Compañía Iberoamericana de Publicaciones, 1930, pp. 33-5) vuelve a criticar la falta de moral, ya no de su obra, sino en su vida, precisamente desde un punto de vista defendido por el vitalismo y que hace referencia a aquella voluntad nietzscheana: O. Wilde, "no fue genial", aunque en muchas cosas admirable; "su vida fue algo lamentable, en que los vicios jugaron con él como las olas con una pavesa de naufragio, puesto que al primer envite de la adversidad se rompió el timón de la voluntad".

${ }^{106}$ Véanse las críticas a Klimt (amanerado, "muy teatral, muy vistoso", "presuntuoso") en "Glosario. Un libro de la Nelken”, El Día n 13.400, 15 de julio de 1917, p. 6. Sobre Zuloaga, entre otras reseñas, trata en su columna "Obras y figuras" de El Día, n 13.205, 31 de diciembre de 1916, p. 6 o en la misma columna, dedicada a la "Exposición José Robledano" (El Día, n 13.200, 26 de diciembre de 1916, p. 6), donde lo considera el mejor pintor europeo del momento. Sobre el expresionismo véase "Obras y figuras. El raro misterio de Bettina Jacometti”, El Día, n 13.193, 19 de diciembre de 1916, p. 6. El expresionismo como clave estética de la literatura de Hoyos lo ha observado Claire-Nicolle Robin, "El expresionismo en Hoyos y Vinent", Angélica 2 (1991), pp. 107-114. Su trabajo pretende conectar la peculiar manera realista de Hoyos y la presencia de lo colorista y grotesco con las tendencias pictóricas y literarias de este movimiento.

${ }^{107}$ Hoyos y Vinent, "Obras y figuras. El escultor Rafael Vela”, El Día n 13.332, 7 de mayo de 1917, p. 6.

${ }^{108}$ Hoyos y Vinent, "Libros de la semana", El Día n 13.539, 5 de diciembre de 1917, p. 6. 
preciosistas y simbólicas) que Luis Antonio de Villena compara con la de Huysmans en su paso del naturalismo a la novela decadente ${ }^{109}$. Aquel cambio tenía consecuencias importantes que afectaban tanto a consideraciones de carácter moral como de naturaleza ideológica. Por lo que respecta a la cuestión moral y en los términos en que lo presenta Pérez de Ayala en Las máscaras, el arte exquisito -el «arte por el arte», que se define por elegir como temas lo extraño, lo raro, lo escandaloso, lo más lejano de las formas habituales de comportamiento-, es reprochable en cuanto supone "la escisión entre la ética y la estética" al contradecir el mismo fundamento de la moral; por el contrario, las categorías estéticas de lo popular y lo artístico nacen de la vida y provienen de ella, "por imitación" Es evidente que las novelas de Hoyos se encuadran en la modalidad que para Pérez de Ayala concluye en un compromiso con lo inmoral, aunque por otro lado sus reseñas demuestren cierto parentesco con las opiniones de su antiguo colaborador cuando juzga en ellas negativamente la posición esteticista que encuentra en el arte y no en la vida la fuente de la inspiración. Si ambos escritores debieron compartir criterios cuando resuelven escribir juntos la comedia Un alto en la vida errante (1904) ${ }^{111}$, años después la perspectiva desde la que concebían el realismo les distanciaría: frente a la fórmula vitalista y «dionisiaca» de Hoyos, el realismo «artístico», que no «exquisito», de Pérez de Ayala.

Por otra parte, la elección de una u otra manera de realismo se asociaba, como adelantábamos, a determinada posición ideológica; en concreto la que propuso Gómez de la Serna y prácticamente todo el nuevo realismo, implicaba una actitud de «compromiso social» heredera de la expresada en las obras juveniles de los autores que suelen agruparse bajo el título de noventayochistas. Partiendo de los planteamientos teóricos de Tolstoi en su ¿Qué es el arte? (traducido en 1902)112 , de Nordau, Ibsen, Nietzsche, Maeterlinck y Guyau (en su replanteamiento de El arte desde el punto de vista sociológico de Taine), el realismo vitalista de Ramón y sus aliados proponía una literatura de la experiencia inmediata, biográfica, trasmisora de sentimientos, en oposición a la literatura intelectual y poco humana del sector "elitista" y clasicista; una literatura que debía tener un fin social, colaborar con la sociedad presente y preparar la nueva ${ }^{113}$, propósitos todos que los acomodaban a los intereses de la literatura de propaganda revolucionaria. De hecho, en la teoría artística del anarquismo, vida y arte se confunden, idea que los Montseny convirtieron en núcleo de su colección de novelas y que tiene íntima raigambre naturalista. Entre las indicaciones de los editores para los autores que colaboran en la colección está,

\footnotetext{
${ }^{109}$ L. A. de Villena, Máscaras y formas del fin de siglo, Madrid, Ediciones del Dragón, 1988, pp. 63-4. Cfr. Alfonso García, Antonio de Hoyos y Vinent, op. cit., pp. 264-5. Matiza sin embargo Alfonso García más adelante (p. 273) que todavía en muchas obras de su época central se mantuvieron los planteamientos básicos del realismo.

${ }^{110}$ Pérez de Ayala, Las máscaras, op. cit., p. 55. Vid. Fernández Cifuentes, Teoría y mercado de la novela, op. cit., p. 140.

${ }^{111}$ Un estudio de esta colaboración en M. Carmen Alfonso García, "El teatro olvidado de un decadentista: Antonio de Hoyos y Vinent", Salina 11 (1997), 149-158.

${ }^{112}$ Sobre las traducciones y ediciones de esta obra, véase L. Litvak, Musa libertaria, op. cit., p. 286, n.1.

${ }^{113}$ Fernández Cifuentes, Teoría y mercado de la novela, op. cit., p. 46 y ss.
} 
más que la aparición de la militancia propiamente dicha, la de que se presenten experiencias vitales de los protagonistas, en su mayoría, eso sí, anarquistas ${ }^{114}$.

No está tampoco de más recordar que aquella nómina de autoridades dictada desde Prometeo fue profusamente divulgada desde las revistas libertarias y sirvió asimismo para configurar la poética del sindicalismo ácrata que después defendiera La Novela Ideal. Entre ellos Maeterlinck, junto con Nietzsche, Taine -y Ruskin-, fue una de las autoridades favoritas de Hoyos en materia literaria. Volvemos a la conexión anarquista ${ }^{115}$.

\section{DECADENTISMO}

La última de las habituales marcas literarias con que la crítica clasifica la obra de Hoyos es la de decadentista. Por decadentismo se entiende en principio un efímero movimiento literario francés (décadisme) que tiene como pórtico y manual de cabecera el À rebours (1884) de Huysmans y en la revista Le Décadent, fundada en 1886 por Anatole Baju, su principal medio. Sin embargo, aplicado a la novela, el término sirve además para caracterizar un género, también de estirpe francesa, ligado tanto al Naturalismo como al simbolismo, de prosa preciosista y tramas dispersas, que tienen como escenario ambientes enrarecidos y como protagonistas personajes hastiados, buscadores de placeres equívocos ${ }^{116}$. La cultivaron Jean Lorrain, Octave Mirbeau (para Hoyos, "el más alto, el más fuerte de los actuales escritores franceses" 117 ), Madame Rachilde y en cierta manera Pierre Louys. Cuando ya apenas quedaba convertida en moda anticuada, encontró en ciertos autores españoles nuevos devotos practicantes entre los que se suele incluir, como el más prestigioso, a Hoyos y Vinent.

El decadentismo de Hoyos quedaría demostrado en la imitación directa de aquellos modelos (se ha venido discutiendo que El monstruo es una versión de El jardín de los suplicios), la similitud de tramas y personajes y el particular estilo. Para confirmar este último aspecto se puede disponer con provecho de la conocida definición del estilo artístico de la 'decadencia' que hizo Paul Bourget en su "Théorie de la décadence" (Essais de psychologie contemporaine, 1883), y que identifica estilo decadente e individualismo en una manera fácilmente aplicable al personal modo de Hoyos de construir sus relatos:

"Un estilo de decadencia es aquel en que la unidad del libro se rompe para dar lugar a la independencia de la página, en el que la página se rompe para dar lugar a la independencia de la oración, y en la que la oración se rompe para dar lugar a la independencia de la palabra"118.

\footnotetext{
114 J. L. Gutiérrez Molina, "La formación de un anarquista", op. cit., p. 107.

115 Sobre cómo estos ingredientes estéticos que tuvieron parte en la formación de Hoyos pudieron influir en su evolución política y dan sentido a su anarquismo trato en otro trabajo: "La trayectoria final de Hoyos y Vinent: Ideología y literatura", Boletín del Instituto y Museo Camón Aznar, marzo-abril de 2001.

${ }^{116}$ L. A. de Villena, "A de Hoyos y Vinent, la pose y la decadencia”, Corsarios de guante amarillo, op. cit., pp. 113-121.

${ }^{117}$ Hoyos y Vinent, "El testamento de Octavio Mirbeau"; El Día, n 13.266, 2 de marzo de 1917, p. 1.

${ }^{118}$ Cito por M. Calinescu, "La idea de decadencia", Cinco caras de la modernidad, op. cit., p. 168.
} 
Modelos, tramas y estilo comparte nuestro autor con los decadentes durante la etapa central de su producción narrativa, y de forma más concreta pueden localizarse además en aquellas obras todos los mitemas que Fátima Gutiérrez enumera como propios de ese momento cultural: perversión, tedio, fascinación por el fracaso y la ruina, mujer fatal y atracción por la muerte ${ }^{119}$.

Precisamente la aproximación metodológica de Gutiérrez al fenómeno de la decadencia desde los presupuestos de la Poética del Imaginario, plantea una visión del término que lo amplía considerablemente sobre las fronteras a las que lo limita la historiografía literaria tradicional, incluso para lo que se refiere a las cronológicas, pues el seguimiento de Gutiérrez concluye, para el caso francés, emplazando el agotamiento de los deltas al término de la primera guerra mundial, cuando "Spengler nos presenta la summa teórica del Ocaso de Occidente"120. De hecho, esta etiqueta del decadentismo, entendida de forma más amplia hasta como habitualmente se ha hecho en nuestra periodología, ayuda a comprender la posición de nuestro novelista en la historia literaria más allá de los concretos parentescos con ciertos modelos franceses, mientras que, según ha sido uso frecuente, reducirla a denominación de pequeña escuela tiene como cosecha, adjudicándosela a Hoyos, comprimirle también como estricto representante de ese mismo género. Superando ese reduccionismo, el decadentismo puede servir para englobar todas las tendencias que surgen del fin de siglo en un espíritu común y que incluso no tiene por qué entenderse en oposición a la corriente naturalista, sino en tensión dialéctica con ella ${ }^{121}$.

Esta acepción más amplia que ahora nos interesa dimana de la primera aproximación teórica que planteara Desirè Nisard en sus Études de moeurs et de critique sur les poètes latins de la décadence de 1834 y que le sirviera para arremeter contra los románticos en general y Hugo, su bestia negra, en concreto. De aquellos Études se deriva la conocida descripción del "estilo decadente" de Paul Bourget que se difundiría con Nietzsche. Desde el estudio de Nisard el estilo de la decadencia se caracteriza por "el uso profuso de la descripción, la prominencia del detalle y, en un plano general, la elevación del poder imaginativo en detrimento de la razón"122, rasgos todos que, por otra parte, la crítica ha observado como los más significativos de la estilística narrativa de Hoyos y Vinent. Como también lo son, el "estilo ingenioso" que aprovecha "colores de todas las paletas y notas de

119 Fátima Gutiérrez, "Mitologías «fin de siglo»: el decadentismo", en Gabriel Oliver, M. Siguán et al., Romanticismo y Fin de Siglo, Barcelona, Universitat de Barcelona-PPU, 1992, pp. 171-8.

${ }^{120}$ Ibid., p. 177.

${ }^{121}$ Para ello puede aprovecharse la interpretación que Calinescu hace de la idea de decadencia en relación con la de progreso, como una relación dialéctica de enorme complejidad, para "llegar a la paradójica conclusión de que el progreso es decadencia e, inversamente, la decadencia es progreso." Lo cierto es que en el fin de siglo convivieron los intelectuales asociados al positivismo naturalista y promotores de una "modernidad esencialmente burguesa, con sus promesas de progreso indefinido", con los "promotores conscientes de una modernidad estética" claramente enfrentada con la primera, y que entendía las promesas del progreso como tácticas alienantes (ibid., pp. 153 y 160$)$.

${ }^{122}$ Así resume Calinescu las consideraciones de Nisard, que éste observó reunidas en el Chants du crépuscule de Hugo y que han servido para caracterizar desde entonces la marca estilística de la decadencia. ("La idea de decadencia", Cinco caras de la modernidad, op. cit., p. 158). 
todos los teclados, luchando por poner en pensamiento lo más inexpresable" y especialmente esa intención de traducir al lenguaje "las sutiles confidencias de la neurosis, las agónicas confesiones de la pasión que surge depravada, y las extrañas alucinaciones de la obsesión que se está convirtiendo en locura", que son las marcas del estilo decadente según la interpretación de Théophile Gautier en sus Portraits et souvenirs littéraires ${ }^{123}$.

Gautier nos lleva a través de esta caracterización del decadentismo literario al terreno donde el concepto supera las marcas formales para convertirse en denominación de una literatura que es confesión de una agonía y de un fracaso confirmado: el del imperio de la razón y de su cómplice la moral. Desde este punto de vista y como se afirmaba antes, el decadentismo es susceptible de aunar todas las tendencias finiseculares hasta la segunda guerra mundial ${ }^{124}$, aglutinando esa literatura que fue resultado de una interpretación de la civilización occidental como acabamiento.

Si el progreso del positivismo, explicaron los Goncourt, tenía como última consecuencia en las conciencias una tensión histérica de la que es resultado la "melancolía moderna", para Zola la "enfermedad del progreso" hacía estragos en la literatura con un "triunfo de los nervios sobre la sangre"125. El modernismo aprovechará y adaptará a sus argumentos espiritualistas esa explicación de raíces fisiológicas: Horacio Quiroga, al tratar de encontrar las causas del modernismo, conecta curiosamente con la versión de aquellos naturalistas:

“¿Quién no ha perdido el equilibrio de sus facultades, quién cree conservar la pureza del tipo fisiológico?

El sentido común da paso al sentido refinado, que es el de los elegidos, de los que han abierto la carrera al Modernismo, y que pronto será el de la masa mediana por la precipitada extenuación de nuestro sistema nervioso"126.

\footnotetext{
${ }^{123}$ Théophile Gautier en sus Portraits et souvenirs littéraires, París, Charpentier, 1881, p. 171. Cit. por Calinescu, "La idea de la decadencia", op. cit., p. 162.

${ }^{124} \mathrm{Y}$ así es también como la usa, aplicada a la periodología, la historiografía literaria italiana. Una puesta al día de los debates sobre el término en Giuliano Ladolfi: "Proposta di interpretazione del Decadentismo", Otto-Novecento (1995), vol. XIX, n 2, pp. 127-169; para Ladolfi el decadentismo comienza hacia 1880 (con Huysman y su $\grave{A}$ rebours y el manifiesto simbolista de 1886) y concluye en los 30 y 40 del siglo XX; pero tiene continuación en el surrealismo, en la escuela hermética (lo que en español se suele denominar "poesía pura"), en las neovanguardias de los años 60 y en la obra final de narradores como Pavese o Camus (ibid. p. 128-9). Para la crítica italiana son decadentistas Kafka, Proust, Joyce, Pascoli, D’Annunzio, Pirandello, Svevo, Roth y Musil. M. Calinescu ("La idea de modernidad", Cinco caras de la modernidad, op. cit., p. 86) se pregunta si será por causa de la influencia de la Iglesia el que en Italia el término modernismo haya mantenido su valor peyorativo, siendo sustituido por la etiqueta periodológica de decadentismo. Sobre el concepto de decadentismo italiano Calinescu proporciona en su libro un resumen muy informativo en el capítulo del mismo nombre (pp. 210-219).

${ }^{125}$ Las citas originales en Calinescu, ibid., pp. 165-166.

${ }^{126}$ Horacio Quiroga, "Aspectos del modernismo", recogido en Prosa modernista hispanoamericana, ed. de José Olivio Jiménez, Madrid, Alianza, 1999, pp. 86-87. Sobre la presencia de razonamientos médicos en la literatura finisecular y su aplicación a las explicaciones de la situación contemporánea es imprescindible el trabajo de Richard Cardwell, "Médicos chiflados: medicina y literatura en la España de Fin de Siglo", Siglo diecinueve 1 (1995), pp.91-117.
} 
Desequilibrio, tensión nerviosa y melancolía se explican en la teoría de la decadencia por el sentimiento de fracaso de toda la tradición occidental científica y filosófica que se vivió en Europa con la crisis del positivismo, al comprobar que tras haber destruido toda posibilidad de certeza, aquella tradición concluía sus afanes destructivos sin proponer una solución al hombre. En este sentido define Ladolfi el decadentismo, no tanto como la vivencia artística de la crisis del positivismo cuanto como "il momento storico in cui la civiltà occidentale assume la consapevolezza della crisis in cui si dibatte da parecchi secoli”"127.

El planteamiento encuentra suficiente confirmación en el sentimiento con que los contemporáneos vivieron la cultura de fin de siglo, que Eugenio D'Ors compara con una ola arrastrándose hacia el nihilismo:

"esta ola es el canto de Tristán e Iseo, que arrastra mentes y conciencias hacia el abismo del amor y de la muerte, sin dejarles otro vigor, antes de que desaparezca para siempre, que el de suspirar una palabra, que es como el testamento de la época: Nihil, ${ }^{128}$.

Esta actitud pesa particularmente en la narrativa y en general en el pensamiento de Hoyos. Bien es cierto que, sobre todo en sus artículos políticos, se hacen constantes llamadas a un ilusionado activismo con el que superar la postración general de los espíritus y que le conectan con los afanes novecentistas: según puede observar, España ha empezado a salir lentamente de su indolencia; desde el momento álgido de la decadencia, que se alcanzó en el 98, viene viviendo un suave ascenso y "se tiene la impresión de un cuerpo que cobra vida". Aprovechando ese nuevo aliento quiere, frente al don Quijote combatidor de molinos, símbolo de la España que malgastó sus energías inútilmente, uno que "defendiéndose contra reales enemigos y acometido a gigantes, tal vez hubiese vencido con la magia de su voluntad. Pensemos todo esto y encaucemos nuestra voluntad y con ella nuestra obra" ${ }^{22}$. Este tipo de exhortaciones a renovar la voluntad (y no olvidemos que el uso de este término en estas fechas nos lleva inmediatamente, como explicaba Mainer, a sus fuentes en Schopenhauer y Nietzsche) es uno de los más insistentes motivos de los “Comentarios" políticos de Hoyos y Vinent en sus colaboraciones para la prensa:

"En la máquina de la vida española, que marcha mal, que se para, que cruje, sólo falta enlazar todas las voluntades, que formen una sola voluntad"130.

\footnotetext{
${ }^{127}$ Ladolfi, "Proposta di interpretazione del Decadentismo", op. cit., pp. 127-169.

${ }^{128}$ Eugenio D’Ors, Glosari, 1906 (cito por Pilar Palomo, "El novecentismo", Movimientos literarios y periodismo en España, Madrid, Síntesis, 1997, p. 349). De esta explicación general, la crítica deduce las características particulares de los géneros a los que se aplica el calificativo de decadentistas: Luis Antonio de Villena afirma que la novela decadente, "es un continuo saberse al final de algo o de varias cosas, y deleitarse en ello", como en "lento paladeo de una agonía". L. A. de Villena, Corsarios de guante amarillo, op. cit., p. 115.

${ }^{129}$ Hoyos y Vinent, "La actuación de la aristocracia en el futuro español", El Día n 13.272, 8 de marzo de 1917, p. 2. Del mismo "Comentario. Orientaciones", El Día n 13.177, 2 de diciembre de 1916, p. 2.

${ }^{130}$ Hoyos y Vinent, "Glosas/ El justo medio", El Día n ${ }^{\circ} 13.183,8$ de diciembre de 1916, p. 3. Véase también su "Comentario a los problemas de la actualidad española", El Día, n 13.248, 12 de febrero de 1917, p. 1.
} 
Pero aquellos afanes vitalistas se resuelven con frecuencia en visiones de profundo pesimismo (cuando no apocalípticas ${ }^{131}$ ) sobre el momento histórico que vive:

"La Humanidad es como una pobre bestezuela que, tras haberse emancipado de su amor, sufre un dolor imposible y no sabe cómo libertarse de él. Después de destruir a los dioses, asistimos a la bancarrota de la sensualidad y el escepticismo [...]. Algunas veces la especie humana me hace el efecto de un Job que, en vez de tierras y rebaños, hubiese poseído todos los placeres y a quien Dios probara con horrenda lepra que, sin creer ya en El y perdido el bienestar material, se revolviera en el estercolero, gimiendo quedamente" ${ }^{\text {"132. }}$.

Las consecuencias de esta situación para la literatura son incuestionables: los autores no pueden seguir trabajando sobre un material vivo, sino sobre esos restos inanimados de una sociedad exánime a la que no queda posibilidad de sanar: frente a los viejos realistas, con los que tantas veces compara la nueva literatura, que aún observaban con indisimulada ternura los vaivenes de sus personajes en un intento de recuperar terapéuticamente para ellos las posibilidades de la salubridad,

“los actuales somos más áridos, más ásperos, más crueles, impíos e indiferentes. No somos el médico [...] que consuela, sino el cirujano que diserta ante sus discípulos operando despiadadamente sobre un cadáver»"133.

No en vano los intentos de autores y personajes decadentistas de construir una explicación de la realidad concluyen siempre en fracaso, dando constancia de aquella premisa fundacional de su edad: la incapacidad del pensamiento occidental moderno para proponer una solución aceptable a las cuestiones existenciales. Ante los exangües despojos cabe sólo ahora el consuelo de la religión: agotadas las posibilidades de la ciencia y la reflexión, los asuntos de la espiritualidad y la mística adquieren enorme importancia y la misma filosofía empieza a explorar la viabilidad de nuevos instrumentos especulativos que no entran en el marco de la razón ${ }^{134}$.

Aunque en Hoyos es perseguible esa inspección religiosa -sobre todo en su afición teosófica, a la que dedicará dos obras en $1924^{135}$-, es la suya una mística que en su trasiego

\footnotetext{
${ }^{131}$ No será ocioso recordar que su primera obra, como demuestra Alfonso García (Antonio de Hoyos y Vinent, op. cit., p. 72), Hoyos se estrena con el cuento "El fin del mundo", publicado en la revista Nuevo Mundo el 16 de abril de 1902; su mismo título parece ya dispuesto a dar cuenta de la posterior atracción del autor por lo apocalíptico. Hans Hinterhäuser (Fin de siglo. Figuras y mitos, Madrid, Taurus, 1980, p. 19), trata de la literatura apocalíptica que tiene sus primeras manifestaciones ya en los años 70 (incluso está presente en Zola) y que puso de moda el tema de "El retorno de Cristo". Una de las versiones más extraordinarias de este asunto la hizo Leopoldo Lugones en La lluvia de fuego (1906).

${ }^{132}$ Hoyos y Vinent, reseña de Carne y espiritu, novela de Emilio Román en "Los libros de la semana", El Día, n 13.208, 3 de enero de 1917, p. 1 .

${ }^{133}$ Hoyos y Vinent, "Libros de la semana", El Día no 13.384, 29 de junio de 1917, p. 4.

${ }^{134}$ Ladolfi, "Proposta di interpretazione del Decadentismo", op. cit., p. 134.

${ }^{135}$ Hoyos y Vinent, El secreto de la vida y la muerte: Exploraciones y El origen del pensamiento: La especie inicial y su bifurcación y ramificación. Aclaraciones y acotaciones; ambas en Madrid, [Suc. de Rivadeneyra, 1924].
} 
con lo erótico se infecta del mismo virus, acaba por aceptar la inutilidad de todo esfuerzo y se hunde en el naufragio del nihilismo total ${ }^{136}$. De ahí las tramas con finales agónico ${ }^{137}$, las rancias familias sin sucesión (recuérdese que Los Buddenbrooks se publica en 1901) y también los escenarios y el decorado que en sus relatos aprovechan todas aquellas asociaciones usuales de la decadencia: declive, crepúsculo, otoño, senectud, agotamiento “y, en sus estados más avanzados, la decadencia orgánica y la putrefacción" $"$, -especialidad esta última muy del gusto de nuestro autor, cuyos personajes más desarrollados son agónicos enfermos infecciosos que exudan ya en sus carnes el pestilente olor de la muerte-.

En su expresión extrema del decadentismo como acabamiento, Hoyos persigue una exploración de la verdad como aniquilación, como demostración de que no cabe salida. Por eso también la investigación de la verdad no se hace -salvo en su obra juvenil o en los últimos títulos- sobre la sociedad de las apariencias, sino en la del vicio, su lado oscuro, donde mejor puede demostrar que hasta los más alambicados recursos de escapatoria acaban conduciendo a ninguna parte ${ }^{139}$. Esta convicción se convierte en motivo central de la mayoría de sus relatos de la época dorada (usando la expresión de Alfonso García) y puede resumirse en el lema con el que abre La hora de la caída (1912): "la hora de la caída tarde o temprano llega siempre. Unas veces surge en plena juventud [...]; otras llega demasiado tarde", pero siempre acabamos cayendo.

El decadentismo en estos límites de desolación sólo puede conducir a una literatura del Mal, igual que la ausencia de futuro es el único destino posible en la negación del Bien, según Bataille: si "el Bien se basa en la preocupación por el interés común, que implica de forma esencial la consideración del porvenir" y aspira a un futuro, el interés por el presente se relaciona con el Mal. El Mal nace de la conciencia de que el futuro no tiene ninguna posibilidad de nacer ${ }^{140}$. Los personajes de esa literatura del Mal a la que tan aficionado fue el marqués de Vinent, confirman con su acabamiento la derrota de la bondad. Así cobra

\footnotetext{
${ }^{136}$ Ladolfi (ibid., p. 148) señala dos etapas en el proceso del decadentismo: el artista, en un primer momento y después de adquirir conciencia del fracaso, busca nuevas vías para reunir la realidad y hacerla inteligible, mientras que en un segundo momento se rinde definitivamente.

${ }^{137}$ Se puede observar cómo muchas de las obras de Hoyos usan el esquema mítico típico de la decadencia. Villena lo señala en Las Hetairas Sabias (1916). L. A. de Villena, "Antonio de Hoyos y Vinent en 1916: Sobre Las Hetairas sabias", Ínsula (1983) XXVIII, 443, p. 10.

${ }^{138}$ M. Calinescu, "La idea de decadencia", Cinco caras de la modernidad, op. cit., p. 153. Sobre algunos tópicos de la decadencia ver también L. Litvak, "Temática de la decadencia en la literatura española de fines del siglo XIX: 1880-1913", España 1900. Modernismo, anarquismo y fin de siglo, Barcelona, Anthropos, 1990, pp. 245258.

${ }^{139}$ Es el escenario de la oscuridad el mismo de la verdad: "amo, sobre todo, la noche, porque en la noche vemos la verdad de los rostros. Durante el día, las gentes llevan careta [...]. Sólo en el misterio de la noche podemos adivinar [...], la verdad de las cosas." Hoyos y Vinent, "Sombras chinescas", relato recogido en Del huerto del pecado, Madrid, Renacimiento, 1910.

${ }^{140}$ Bataille, La literatura y el mal, Madrid, Taurus, 1987, p. 27.
} 
sentido la fascinación de uno de los alter-ego de Hoyos, el escritor Lorenzo Álvarez de Salazar, por la abyección y la miseria:

"mi vida es una de esas vidas que tienen que empezar con uno y concluir con uno; ni raíces en el ayer ni ramas en el mañana... Mi vida soy yo"141.

Como en Baudelaire, la convicción del Mal en la ausencia de futuro invita a la búsqueda de novedades que hagan más atractiva una existencia sin sentido; de ahí el afán de Aventura (con mayúscula, especifica el autor) del propio Hoyos y la curiosidad que le ha empujado "a través de la noche", dejándose "resbalar por todos los toboganes que hallé al paso y deslizarse por todas las montañas rusas y water chuts que vi" "142. De ahí también el descenso a los infiernos y la colección de perversidades que nacen del deseo de distraer el tedio, convertido en motor de la acción en cuanto la dirige a nuevas experiencias (desde María de la Paloma en El crimen del fauno a la Helena Fiorenzio de El monstruo).

Este consumarse del decadentismo en la inmoralidad fue la principal arma con la que la Entartung (1892-3) de Nordau atacó a los escritores de su tiempo, observándolos como producto de una patología que asola Europa y de la que es consecuencia esa nueva literatura de amarga reflexión, abulia y falta de sentido vital, bullidero al fin de toda clase de depravaciones. En el caso español -aunque no en exclusiva-, esa enfermedad se interpretó con la conciencia de estar viviendo el momento final de la raza ${ }^{143}$ y la novela abundó en protagonistas ejemplares de aquella decadencia, coincidiendo por otra parte con una tipología de personajes que fue la más habitual en la literatura finisecular ${ }^{144}$.

Si una de las consecuencias de la crisis decadentista es que el hombre no se siente capacitado para llevar a cabo acciones auténticas, cargadas de significado, sino que se pierde en actividades estériles, superficiales, los protagonistas de sus narraciones devolverán especularmente la ineptitud, sensación de fracaso y falta de ideales. "È l'uomo che si lascia vivere"145, son los vencidos, incapaces de afrontar la vida, conscientes de su propia inutilidad, de lo superfluo de su propia presencia en el mundo, demostración viva de que no existe ningún ideal moral capaz de levantar un puente de autenticidad entre las

\footnotetext{
${ }^{141}$ Hoyos y Vinent, Las lobas del arrabal, op. cit., p. 53.

${ }^{142}$ Artemio Precioso, prólogo-entrevista para La celada, (colección La Novela de Hoy, 30 de junio de 1922, p. 6) y El primer estado, Madrid, CIAP/Renacimiento, 1931, p. 195.

${ }^{143}$ El Sangil de La Hora Trágica (1909), segunda entrega de la trilogía Historia de un escéptico de Alberto Insúa, explica: "han luchado mis antepasados, ha luchado mi raza... El cansancio me toca a mí... en España, nuestra generación no tiene otra cosa que hacer sino rendirse al cansancio" (cito por Isabel Román Gutiérrez: "Aproximación a la Historia de un escéptico, de Alberto Insúa", op. cit., p. 339). A pesar de la alusión a lo nacional, Sangil se demuestra un enfermo de decadencia a la medida europea ya que, según Román, la razón fundamental de su pasividad "es su falta de amor por la vida": ya no le quedan esperanzas de redimir al hombre; "¿para qué luchar?", se pregunta el personaje: "Yo he reducido el mundo al mundo de mis sensaciones y la patria a mi casa."

${ }^{144}$ Nil Santiáñez-Tió, "El héroe decadente en la novela española moderna (1842-1912)", Boletín de la Biblioteca Menéndez Pelayo LXXI (1995), pp. 179-216.

${ }^{145}$ Ladolfi, "Proposta di interpretazione del Decadentismo", op. cit., p. 162.
} 
personas: por eso se abandonan en amistades superficiales, palabras vanas, el refugio en el alcohol o la fantasía, que ni siquiera les bastan para engañarse.

El primer camino de perfección que preparó Hoyos para este personaje tipo fue Mors in vita (1904), historia de Álvaro Navarrete, perdedor desde que el título mismo de la novela le condena a la única alternativa de la muerte ${ }^{146}$. Pero también Xavier Moncada, el protagonista de El horror de morir (1915) es un ser sin voluntad, impotente y neurótico; como Casiano, en La procesión del Santo Entierro, enfermo e hiperestésico, o la Helena Fiorenzio de El monstruo (1915), "verdadero poema lírico de la disolución y pulverización del ser a través de la lujuria"147, versión femenina de este ser agónico. A tenor de la galería, que podría alargarse mucho más, no en vano Pardo Bazán en su prólogo a La atroz aventura (1918), se queja de que los personajes de Hoyos sufren de "la inmoralidad más grave, que es la carencia de voluntad"148. Sólo la evolución de sus convicciones ideológicas hacia el Ideal anarquista de sus últimos años abrirá desde 1927 otras posibilidades a sus seres de ficción.

Si la novela intelectual ensayó primero estos caminos de perfección sin salida en los personajes de Baroja o Azorín, la "promoción de El Cuento Semanal" supo trasladar después a otra medida aquella tipología convertida en lugar común ${ }^{149}$. En unos y otros, aquella Bildungsroman romántica que conducía al despertar de la vida interior, se ha transformado en un aprendizaje que, como señala Urrutia, "conduce, de algún modo, a la muerte"150. Asistimos así al final de la trayectoria de un género que vivió de investigar la compleja relación entre arte y burguesía y que Lukács hace iniciar en Goethe y concluir en Thomas Mann, notario de la definitiva ruptura entre mundo burgués y conciencia estética ${ }^{151}$. Y cuando el arte no puede seguir siendo compatible con la forma de vida burguesa, épater le bourgeois significa en sí mismo una reivindicación de la belleza.

No podemos cerrar este capítulo de la estética de Hoyos sin mencionar cómo también el decadentismo nos pone en la pista de la conexión libertaria. Como se ha apuntado arriba, los mismos 'decadentes' de la escuela francesa insistieron en las vinculaciones entre esteticismo, anarquismo y moral antiburguesa, precisamente porque, como recuerda $\mathrm{E}$. Wilson en su Castillo de Axel, el poeta siente que no puede combatir al todopoderoso burgués, "el sentido destructor del terrorismo anarquista le fascina y sus versos quieren ser

\footnotetext{
${ }^{146}$ Un análisis de la novela en Alfonso García, Antonio de Hoyos y Vinent, op. cit. p. 116ss.

${ }^{147}$ Nora, La novela española contemporánea, op. cit., p. 417.

${ }^{148}$ Cito por Alfonso García, Antonio de Hoyos y Vinent, op. cit., p. 228.

${ }^{149}$ Isabel Román Gutiérrez estudia la versión de este personaje que hizo Insúa en Historia de un escéptico (19071909) a través de Alfredo Sangil "abúlico, inactivo y sensual", cuya trayectoria lo conecta con dos novelas de 1902, Camino de perfección y La voluntad, así como con la tetralogía de Pérez de Ayala: Tinieblas en las cumbres (1907), AMDG (1910), La pata de la raposa (1912) y Troteras y danzaderas (1913). I. Román Gutiérrez, "Aproximación a la Historia de un escéptico, op. cit.

${ }^{150}$ Jorge Urrutia, "Estructura, significación y sentido de Sonata de otoño", Philologica Hispaniensia IV, (1987), pp. 452-3.

${ }^{151}$ G. Lukács, Thomas Mann, Barcelona, Grijalbo, 1969.
} 
dinamita artística, bombas estéticas". El anarquismo 'literario' no deja de ser otra de las formas de «épater le bourgeois»" ${ }^{152}$ o incluso, como lo ve Julio Camba desde sus posiciones conservadoras de madurez, otro de los «paraísos artificiales» ${ }^{153}$. La relación, más allá de lo ideológico, encontraba sus argumentos fundamentales en la compartida heterodoxia, la violencia con que unos y otros se enfrentan al orden establecido y en la ausencia de reglas o programa, comunidad que debió bastar para hacerles sentir a los poetas del mismo lado que los anarquistas. El resultado es que, como afirma Calinescu, "los «decadentes» a menudo sostenían creencias revolucionarias" y "el anarquismo les resultaba particularmente atractivo"154. (Recordemos también que incluso Mallarmé fue simpatizante del anarquismo, y Oscar Wilde habló en defensa de la utopía y pronosticó el triunfo de un socialismo fuertemente teñido de anarquismo en su Intentions and the Soul of Man under Socialism).

La misma Théorie de la décadence que esboza Paul Bourget en su trabajo sobre Baudelaire publicado en la Novelle revue (1881), da una explicación de la decadencia de tipo sociológico según la cual las sociedades en decadencia se caracterizan por el individualismo, el aumento de la anarquía y la relajación de las relaciones jerárquicas en el entramado social, confirmando la vinculación de esteticismo y radicalismo ideológico. Lo cierto es que después de $A$ Rebours, "el esteticismo decadente se hace más consciente de sus funciones polémico-críticas" y lejos de mantenerse al margen de los compromisos morales o políticos, fue evolucionando "hacia una defensa abierta de las ideas revolucionarias"15s.

El repaso por los distintos modos literarios y propuestas estéticas que tuvieron parte en la obra literaria de Hoyos concluye presentando un panorama híbrido y una poética heterogénea cuyas ramificaciones tejen un complejo entramado en el que lo sociológico y lo ideológico muestran continuamente su tensión con lo estético. Ante este abigarrado tapiz, las demarcaciones periodológicas que pretenden construir la historia literaria como una secuencia de movimientos se demuestran muy poco útiles; confirma el caso de Hoyos su escasa funcionalidad una vez llevadas al análisis directo de un autor y especialmente para

\footnotetext{
${ }^{152}$ Aznar Soler, "Decadentismo y bohemia literaria", op. cit., p. 29.

153 "La Anarquía era para nosotros, más que una concepción filosófica, un entretenimiento sentimental. En cualquier velada de teatro, en cualquier mitin o en cualquier manifestación pública, la Anarquía tenía expositores elocuentes, mujeres hermosas y canciones aladas; tenía un espíritu alegre, aventurero, generoso y artístico; todo lo cual mantenía el entusiasmo de los viejos y suscitaba el de los jóvenes. [...] Justo, sutil y poderoso es también el veneno de la Anarquía, y ningún fumador de opio, ningún bebedor de ajenjo, ningún tomador de morfina ni de haschís, ha tenido sus sueños poblados de visiones más hermosas que las visiones que pueblan el gran ensueño anarquista. La Anarquía es también uno de los paraísos artificiales". Julio Camba, El destierro; Madrid, colección El Cuento Semanal, 25 de octubre de 1907, p. 35.
}

${ }^{154}$ Calinescu, "La idea de decadencia", op. cit., p. 160. Aznar Soler ("Decadentismo y bohemia literaria", op. cit., pp. 28-30) transcribe un ejemplo de esta confluencia en las declaraciones de Alfred Vallette, publicadas en Mercure de France en 1889 y que recoge Iris Zavala en su "Estudio preliminar" de las Iluminaciones en la sombra de Sawa, pp. 7-8: "No tenemos programa, cada cual es libre de expresar su pensamiento; eso sí, todos coincidimos en una visión heterodoxa del mundo, en una «nueva moral» que defiende lo anticonvencional [...] La nuestra es una literatura militante: somos soldados de la belleza".

${ }^{155}$ Calinescu, "La idea de decadencia", op. cit., 172. 
las figuras que, como la suya, no pertenecen a las listas de grandes nombres con las que se confeccionan las de «características» de época o escuela. En palabras de Mainer que valdría la pena recordar con más frecuencia, "no hay peor enemigo de la historia literaria que la fosilización de unas características de grupo en función de momentos cronológicos determinados." 156

El término de Novecentismo resulta impropio aplicado a una fracción temporal (19141920?) o generacional y requiere una revisión que lo plantee como encrucijada de caminos viejos y nuevos senderos -material del que se construyen al fin todos los periodos históricos-, en el contexto de una profunda transformación de los medios de producción y difusión de la literatura. En cuanto a la etiqueta de Modernismo resulta peligrosamente lábil mientras se mantenga asociada a valores más formales que conceptuales. Por el contrario, el concepto de Decadentismo, interpretado en la historiografía literaria española como un ingrediente temático de ciertos géneros particulares, posee en su favor el conjugar unas características formales con una actitud metafísica que, como su uso demuestra en la crítica italiana, sabe dar razón del espíritu literario europeo en este primer tramo del siglo XX.

Quizá podría aquí aprovecharse la revisión de Fokkema a la teoría sistémica de Luhmann, cuando afirma

"Smaller systems are not necessarily the product of internal differentiation ('Ausdifferenzierung') of larger systems; they can also be hybrids deriving from heterogeneous systems."'157

El concepto de Decadentismo puede usarse como "small system" para referirse a un movimiento francés concreto o a uni género insertado en una corriente más general; pero si se observa en la riqueza de su hibridismo quizá ofrezca la posibilidad de comportarse como un "large system" que nos explique, en este caso particular y quizá -habría que probarlo- en otros muchos, que la heterogeneidad literaria de Hoyos conforma, en su misma contradicción, un sistema homogéneo.

\footnotetext{
${ }^{156}$ Mainer, "La llamada generación del 98: otros puntos de vista”, op. cit., p. 32.

${ }^{157}$ Douwe Fokkema, “Changing the Canon: A Systems Theoretical Approach", en E. Ibsch, Dick Schram y G. Steen (eds.), Empirical Studies of Literature, Ámsterdam, Rodopi, 1991, p. 363.
} 